\title{
AN ESTIMATION OF THE EXTENT OF CROPLAND ABANDONMENT IN MOUNTAINOUS REGIONS OF CHINA
}

\section{running head: AN ESTIMATION OF THE EXTENT OF CROPLAND}

\section{ABANDONMENT IN CHINA}

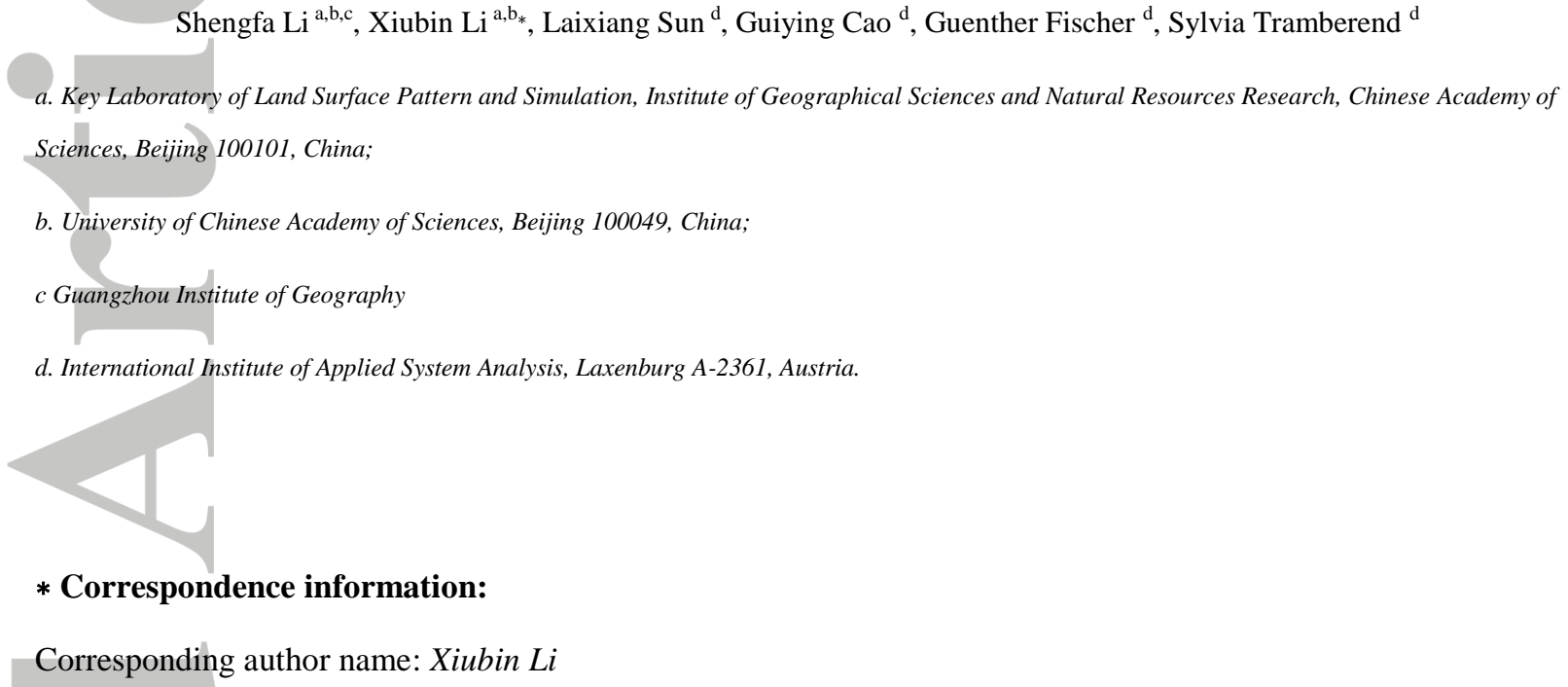

Corresponding author name: Xiubin $\mathrm{Li}$

Affiliation: Institute of Geographical Sciences and Natural Resources Research, Chinese Academy of Sciences Address: 11A, Datun Rd., Chaoyang District, Beijing, China

Email:lixb@igsnrr.ac.cn

Telephone: 86-10-64889297

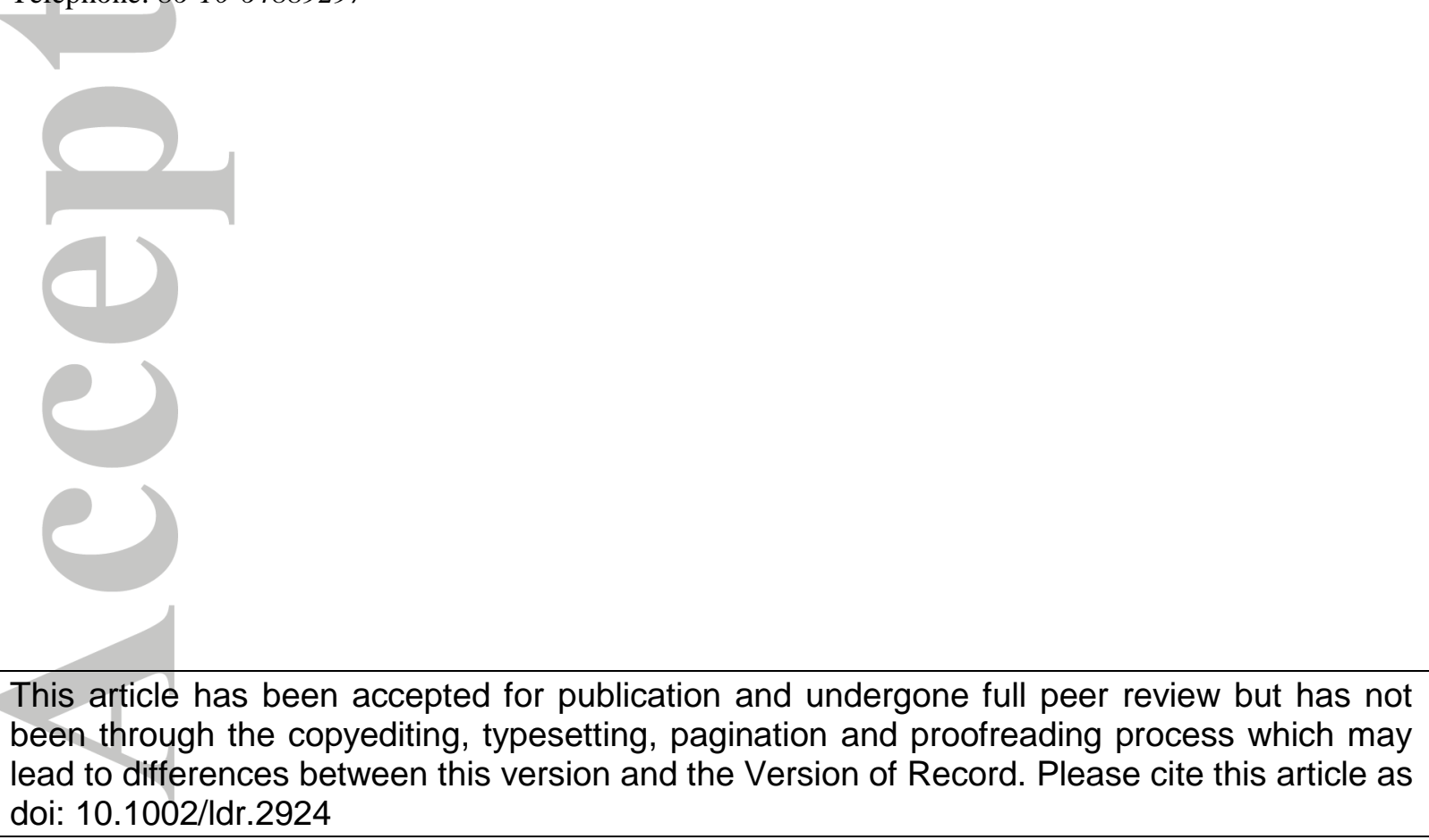




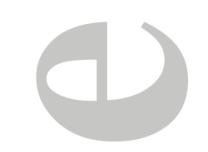

\section{Abstract}

With the wages for migrant workers increasing dramatically in China since 2003, the size of the agricultural labour forces has been shrinking rapidly. Intensively substituting agricultural machinery for the shrinking farm labour force is hardly possible for croplands in the mountainous regions of China where mechanization is difficult to achieve due to small field size and rough terrain. This has eventually led to cropland abandonment in these regions. Considering the high pressure for food security in China, cropland abandonment in the mountainous regions should not be ignored. By employing a novel method, this study estimates the extent of recently abandoned croplands (period 2000-2010) and the changes that can be expected in the future in China's mountainous areas. The results show that the total extent of abandoned croplands in Chinese mountainous counties during the period 2000 to 2010 is estimated at 147 million mu ( $\left.1 \mathrm{mu}=666.67 \mathrm{~m}^{2}\right)$; in total, about $28 \%$ of croplands in mountainous counties was abandoned, including croplands converted in the Grain for Green Programme (GGP). With three scenario assumptions, a sizeable extent, 114 to 203 million mu, of croplands may be abandoned from 2010 to 2030 with the rapid decrease and aging of projected farm labour forces. This could exacerbate the future challenges of maintaining China's food security. A substantial increase in agricultural project investments, including land consolidation and agricultural productive fixed assets, especially micro-tillage machines, could help mitigate the risk of cropland abandonment. Additionally, land-use and environmental policymaking should take into account the expanding cropland abandonment in mountainous regions.

Keywords: cropland abandonment; agricultural labour productivity; population projection; mountainous regions; China

\section{Introduction}

The widespread occurrence of cropland abandonment, defined as the cessation of farming on a given arable land and usually followed by natural revegetation (Cramer et al., 2008; Prishchepov et al., 2012), has been observed in many developed countries (Moravec \& Zemeckis, 2007; Pointereau et al., 2008; Ramankutty \& Foley, 1999; Shoyama \& Braimoh, 2011) and some developing countries (Müller et al., 2012; Parés-Ramos et al., 2008; Perz $\&$ Skole, 2003). It often occurs in mountainous regions due to the steep slope that challenges farming (Li \& Li; et al, 2017; MacDonald et al., 2000). Abandonment of cropland, which is one of the most important stages of forest transition, has been considered the outcome of industrialization and urbanization by forest transition theory (Barbier et al., 2010; Grainger, 1995; Mather \& Needle, 1998; Rudel et al., 2005). Rural-urban migration and the reduction in agricultural labour forces have been invoked as the main drivers leading to cropland abandonment of marginal areas in developed countries (Izquierdo et al., 2008; Izquierdo \& Grau, 2009; Mather, 1992; Melendez-Pastor et al., 2014; Rudel et al., 2002; Rudel et al., 2005; Verburg et al., 2010) and the mountainous regions of China (Shao et al., 2015; Zhang et al., 2014b; Yan et al., 2016). Cropland abandonment has strong environmental and socio-economic impacts and consequences, such as conflicting biodiversity changes (Izquierdo et al., 2008; Queiroz et al., 2014; Woodhouse S P, 2005), carbon stock increase (Schierhorn et al., 2013; Shang et al., 2014; Wang et al., 2011), fire hazards (Moravec \& Zemeckis, 2007), soil erosion (Cerda, 1997; Zeller et al., 2001), anabatic poverty (Khanal \& Watanabe, 2006), and marginalization of historic 
agricultural landscapes (Elbakidze \& Angelstam, 2007; EU, 2004).

With migrant worker wages increasing dramatically in China since 2003 (Zhang et al., 2011), young and middle-age peasants prefer seeking employment in urban areas for higher income and better life. Therefore, the size of agricultural labour forces has been shrinking rapidly from 362 million in 2003 to 241 million in 2013 (CSY, 2014). The striking increase in farming opportunity costs have led to a rapid rise in agricultural labour costs for production ( $\mathrm{Li} \& \mathrm{Li}, 2016$ ), thereby substantially lowering the agricultural production profits (Tian et al., 2009). Consequently, in plain areas, agricultural machinery is intensively used instead of the increasingly expensive farm labour force, and resulting in large-scale modern agriculture (Chen \& Li, 2009). However, this is hardly possible for croplands in the mountainous regions of China, where mechanization is difficult to achieve due to small field sizes and rough terrain, which has led to the marginalization and even abandonment of croplands in these regions (Li \& Zhao, 2011; Yan et al., 2016). As new urbanization strategies have been carried by the Chinese government recently, the massive migration of rural and farm labour forces may continue in the near future. Therefore, cropland abandonment will very likely increase with the reduction in rural labourers and aging of agricultural labourers (Lu \& Yang, 2012; Shao et al., 2015). China has the largest population in the world, while its average cropland area per person is only half the world's average. Moreover, mountainous areas account for $2 / 3$ of China's total territory, about a quarter of China's total cropland, and $14 \%$ of grain yield in 2010. Considering the ongoing processes of rural to urban migration, as well as aging, in mountainous rural regions of China, the probable widespread cropland abandonment may not only affect the regional natural environment and ecosystem, but also food security in China. Thus, it is necessary to estimate the extent of abandoned cropland and its future trajectories, which may facilitate informed policymaking of land-use and agriculture.

Remote sensing techniques, which are the most popular and efficient method to map the extent of abandoned cropland and estimate the abandoned rate, has been widely applied to detect the farmland abandonment in Europe: Central and East Europe (Alcantara et al., 2013; Kuemmerle et al., 2008; Prishchepov et al., 2012), West Europe and the Mediterranean region (Corbelle-Rico et al., 2012; Gellrich \& Zimmermann, 2007; Weissteiner et al., 2011). Several types of remote sensing data with different resolution, including SPOT (Milenov et al., 2014), TM/ETM+ (Kuemmerle et al., 2008; Müller et al., 2012), MODIS (Alcantara et al., 2013; Alcantara et al., 2012) and AVHRR (Weissteiner et al., 2011), have been used to extract abandoned farmland in previous studies. In addition to remote sensing data, high-resolution aerial photographs have also been used to map the extent and distribution of abandoned cropland (Cohen et al., 2011; Doorn \& Bakker, 2007; Pueyo \& Beguería, 2007). Abandoned cropland, with early-successional regrown grass and shrubs, is hard to distinguished from managed cultivated land using single season remote sensing imagery (Kuemmerle et al., 2008; Oetter et al., 2001). Therefore, using multi-seasonal imageries to capture the dynamic features of land use is usefully when classifying agricultural land use and natural vegetation covers characterized by seasonal gradually changes (Guerschman et al., 2003; Lasanta \& Vicente-Serrano, 2012; Oetter et al., 2001), especially when capturing agricultural land abandonment (Prishchepov et al., 2012). MODIS and AVHRR, with seasonal NDVI or EVI have advantages in monitoring land-use and land-cover dynamics in the regions where agricultural fields tend to be larger and homogeneous, such as Russia, Ukraine and USA (Alcantara et al., 2013; Alcantara et al., 2012; Ozdogan \& Woodcock, 2006). However, the coarse-resolution (250 m to $1 \mathrm{~km}$ ) of these remote sensing data will lead to large errors in area estimates in the regions, such as China, where cultivated land is highly fragmented (Ozdogan \& Woodcock, 2006; Xiao et al., 2003; Yan et al., 2016). According to the national rural household survey data from 2000 to 2009 by Chinese Ministry of Agriculture, the average plot 
size of cropland in China was $1.52 \mathrm{mu}$ and the average plot size in hilly western China was only $0.9 \mathrm{mu}$ (RPOSS office, 2009). Our household survey in the mountainous city of Chongqing showed similar values, ranging from $0.44 \mathrm{mu}$ to $0.97 \mathrm{mu}$. Thus, the existence of mixed pixels from the high fragmentation of cultivated land in China, especially in mountainous area due to complicated topography, may result in unacceptably high errors, even using Landsat data (30 m) (Ozdogan \& Woodcock, 2006; Xiao et al., 2003). Furthermore, NDVI and TM data were examined and found unsuitable for mapping cropland abandonment in Chinese mountainous areas (Cheng, 2011).

High-resolution ( $1 \mathrm{~m}$ to $20 \mathrm{~m}$ ) satellite images (e.g., SPOT5, QuickBird) and aerial photos are very popular in small area studies for their high accuracy in mapping highly fragmentized land-use (Cohen et al., 2011; Doorn \& Bakker, 2007; Milenov et al., 2014; Pueyo \& Beguería, 2007). Considering the vast area of Chinese mountain, using high-resolution images seems impractical because of the herculean task. More importantly, the interpretation of remote sensing data cannot provide us future trends in cropland abandonment. Accordingly, we developed a non-remote-sensing, indirect and easier method to estimate the current and future extent of abandoned cropland in mountainous regions after 2000. The method is based on the mechanism of cropland abandonment, and will contribute to designing better-informed agricultural policies.

\section{Methods}

\section{General framework for the estimation}

Research has confirmed that land marginalization, which was precipitated by drastic increases in farming opportunity costs, was the primary driving force for farmland abandonment ( $\mathrm{Li} \& \mathrm{Zhao}, 2011 ; \mathrm{Li} \& \mathrm{Li}, 2016$ ). In response to profit losses caused by rising labour costs, farmers have transitioned to labour-saving machinery to replace expensive agricultural labour (Xin et al., 2011; Zhu et al., 2007), but this is not the case for cropland in mountainous areas. The steep slopes and cropland fragmentation in mountainous regions lowers accessibility and availability for agricultural machinery (Li \& Zhao, 2011; Yan et al., 2016), therefore, farmers in mountainous usually choose to plant more high-labour-productivity crops (Tian et al., 2009). Nevertheless, such adjustment in farming practices through structural change is limited. During the process of land marginalization, some famers may switch from intensive land use to labour extensive production to reduce labour input, which allows farming of larger land areas. However, after reaching the Lewis turning point, the increase in average cultivated area per labourer by extensive farming is likely to be marginal in mountainous areas due to long farming distances, poor transportation and farmland fragmentation; this could induce diseconomies of scale for expansion of farming in mountainous areas. According to our household survey in mountainous China, many farmers would like to plant labour-intensive crops (e.g., flue-cured tobacco and herbs) with high revenue on less land area, and abandon poor and remote cropland.

In fact, the expansion of the average cultivated area per labourer is mainly due to the development of agricultural machinery (Hayami \& Ruttan, 1971; Ellis, 2006). The differences in farming conditions between mountainous and plains areas result in their different labour productivity results. The household survey data from the Rural Permanent Observation Sites Survey (RPOSS) indicated that the average cultivated area per labourer in mountain villages remained relatively constant from 2000 to 2009 (Figure 1), while there was an obvious increase since 2003 in plain villages (RPOSS office, 2009). Hence, in the context of little or no input of agricultural machinery, with growing migration of agricultural labourers induced by urbanization, industrialization and land marginalization after the Lewis turning point, and rural households not allocating enough labour to farm land without the machine replacements, marginal farmland in mountainous will be abandoned (Shao et al., 2015; Yan et al., 2016). 
Although the migration is not the primary cause underlying cropland abandonment, the shortage in agricultural labour forces due to migration is the direct cause and noticeable characteristic in mountainous areas ( $\mathrm{Li} \& \mathrm{Li}, 2016$ ), which has been discussed thoroughly in many studies, including case studies in Chinese mountain regions (Shao et al., 2015; Tian et al., 2010; Yan et al., 2016). Because the average cultivated area per labourer has maintained stability in Chinese mountainous areas, the change in the quantity of agricultural labour forces provides the key for estimating the extent of abandoned cropland. Specifically, we can estimate total managed cropland by estimating the average cultivated area per labourer and size of the agricultural labour force, and thereby derive the extent of abandoned cropland (unmanaged cropland) by subtracting the managed cropland area from total cropland area (Figure 2).

The total cropland before abandonment can be obtained using remote sensing techniques. According to existing literature, Chinese cropland area began to decline in 2000 (Liu et al., 2014; Liu et al., 2009; Liu et al., 2003). Moreover, in rural China, the Lewis turning point arrived in 2003, indicating the beginning of China's nationwide labour shortage and the disappearance of the surplus labour from rural areas (Zhang et al., 2011). Therefore, we use cropland data from 2000 to represent the cropland before abandonment. Because China initiated the "Grain for Green" (GGP) program in 1999, with the purpose of mitigating and preventing soil erosion by converting sloping cropland to forest and grassland, the abandoned cropland here actually includes two components: cropland voluntarily abandoned by farmers and cropland converted to forest and grassland by GGP. Because GGP was implemented in mountainous China and also in hilly and land desertification areas, we cannot acquire detailed reforested cropland data by county. Therefore, in this study, we estimate the total extent of abandoned cropland including these two parts. In terms of land marginalization, cropland reforestation is another kind of abandonment, but passive, as Chinese government paid farmers to cease farming marginal croplands that were likely to be abandoned soon.

The amount of managed cropland is determined by two factors: the number of agricultural labourers living in the village (include part-time farmers) and the cultivated area per agricultural labourer (CAPAL, the average cropland area a farmer will manage). More farmers and a larger average managed cropland area per farmer results in a larger area of managed cropland. Thus, the managed cropland is the product of the size of the agricultural labour force and cultivated area per agricultural labourer.

$$
M C L=A L F \times C A P A L
$$

where, $M C L$ is the area of managed cropland, $A L F$ is the size of the total agricultural labour force, and $C A P A L$ is the cultivated area per labourer.

$$
A L=T L \times M C L
$$

where, $A L$ is the area of abandoned cropland, $A L$ is the area of total cropland before abandonment.

We employed a regression model to estimate $C A P A L$, and use statistical and census data to estimate $A F L$. The size of future agricultural labour forces is projected based on a PDE model developed by IIASA, combined with reference to RPOSS data. Due to the lack of household survey data, except for the model construction of CAPAl, other estimations are provincial-level results.

According to UNEP-WCMC criterion, an area can be defined as mountain when its elevation is over 2500 $\mathrm{m}$; or its elevation between $1500 \mathrm{~m}$ to $2500 \mathrm{~m}$ has a slope over $2^{\circ}$; or its elevation between $1000 \mathrm{~m}$ to $1500 \mathrm{~m}$ has a slope over $5^{\circ}$ or local elevation range over $300 \mathrm{~m}$; or the elevation between $300 \mathrm{~m}$ to $1000 \mathrm{~m}$ has a local elevation range over $300 \mathrm{~m}$ (Price \& Butt, 2000). However, mountainous regions are not identical to a defined mountain, because it is a continuous and integrative area, which should be defined by the physical characteristics and socio-economic factors (Jiang \& Zeng, 2009). Most social and economic statistic data are collected at the county scale. As a result, we chose mountainous counties as our study area; the list of 
mountainous counties was obtained from the China County Statistics Yearbook (CCSY).

China has around 900 mountainous counties, which are mainly distributed in southwest China (Figure 3, a). These 900 mountainous counties accounted for $45.6 \%$ of China's land area and $26 \%$ of China's cropland area in 2000 (Figure 3, b). CCSY specifies the mountainous county as a county with $80 \%$ or more mountainous area; we find a perfect match between the distribution of mountainous counties and patterns of elevation and slope (Figure 3, c, d).

Potential explanatory variables for the Regression model of CAPAL

Previous work has revealed that agricultural labour productivity, measured by yield per labourer or income per labourer, is related to various inputs of labour, land, capital and technology (Hayami \& Ruttan, 1971; Fan \& Zhang, 2002). Because we use cultivated area per labourer as a proxy for agricultural labour productivity, and the labour input has been converted into standard labour, we employed agricultural productive fixed assets per labourer $(A P F A P L)$ and draught animals/farm cattle per labourer $(D A P L)$ as the capital and technology input. Fertilizer input is an irrelevant variable to $C A P A L$, so it was not included in this model.

In addition to the capital and technology input, there are some other variables that limited the increase of $C A P A L$, thereby resulting in cropland abandonment. Abundant studies have shown that slope, elevation, farming distance, plot size, number of plots, land market and wild animal attacks have significant impacts on farmland abandonment (Yan et al., 2016; Terres et al., 2015; Keenleyside and Tucker, 2010; Pointereau et al., 2008; Shao et al., 2015; Xie et al., 2014; Zhang et al., 2014a).

High elevation and steep slope is a good indicator of land abandonment as it requires high labour input (Shao et al., 2015; Xie et al., 2014; Zhang et al., 2014a) and has limited accessibility to agricultural machinery (Mottet et al., 2006). Hence, the high elevation and steep slope could be impediments for increasing labour productivity. Due to the lack of data from high elevation and steep slopes of the survey villages, and the high correlation between land use type and terrain condition in China (Li \& Dong, 2013; Chen et al., 2012), we used the ratio of percent forest area to percent cropland area (FCINDEX) in a village as a proxy for elevation and slope. In addition, FCINDEX also indicates the possibility of wild animal attack, which has become a very important driver of cropland abandonment in China due to the need for manpowered guarding during the harvest seasons (Yan et al., 2016).

A positive relationship exists between farm size and labour productivity (Fan \& Chan-Kang, 2005). Small plot sizes have been identified as determining factors for cropland abandonment in many mountainous areas (Yan et al., 2016; Mottet et al., 2006; Lemel, 2000). Therefore, land consolidation can help improve labour productivity (Sklenicka, 2006). Farming distance or commute time is another key determinant of cropland abandonment in mountainous areas of China (Zhang et al., 2014a; Shao et al., 2014), but we have no data for average farming distance. Hence, we used average plot size (APS) as a proxy for land fragmentation, which embodies some impacts of farming distance and commute on labour productivity (Yan et al., 2016).

Land markets may affect labour productivity when poor land markets prevent croplands from being transferred to younger and more productive farmers (Deininger \& Jin, 2009), as well as reconstitution of viable farming units through land consolidation (Terres et al., 2015). As a consequence, improving land marketing contributes to increasing a farmer's labour productivity (Mao et al., 2015), and thus to preventing abandonment of farmland with high-grade farming conditions (Zhang et al., 2014a; Shao et al., 2016). Thus, we employed a Land rental rate as a proxy for land market. 
Furthermore, the multiple cropping index $(M C I)$, the proportion of paddy fields in croplands $(P P F)$, may influence CAPAL. MCI in south China, with a longer growing season, is larger than in north China. The farming time per mu is longer in larger $M C I$ areas, which means $C A P A L$ may be smaller in these areas. Mountainous area paddy fields have a lower risk of abandonment than non-irrigated farmland (Shao et al., 2015), because paddy fields are mainly located in flat areas and near residences, which reduces farming time. Thus higher $P P F$ leads to higher CAPAL.

Finally, district dummies are included to capture unobserved factors, including district-specific policy decisions and agro-ecological conditions, and the district-specific farming systems and resulting habits. We employed the agriculture zones in which villages are located as dummy variables in the regression model. The agriculture zones are Northeast region, Inner Mongolia and Great Wall region, Huang-Huai-Hai region, Loess Plateau region, Gansu-Xinjiang region, the middle and lower reaches of Yangtze River, South region, Southwest region, and Tibet Plateau region. We took Northeast region as a reference. According to the rural household survey, the northern area of China has a larger CAPAL than the south.

All variables are listed and described in Table 1.

Data processing

(1) Filtering agricultural household data. Different crops require different farming time effort. Generally, non-grain crops, such as vegetable or tobacco require more than three times the farming time than grain crops (S1), implying that the area of non-grain crops per farmer is less than the area of grain crops per farmer under the same constraints. Hence, these non-grain crops data will lead to an underestimation of CAPAL and should be eliminated. As non-grain crops are non-staple in mountainous regions we eliminate these inappropriate data through the selection of "grain households", which is defined as sown area of grain crops of an agricultural household larger than four-fifths of its total cropland area.

(2) Conversion of labour force into standardized agricultural labour. Cropland areas are tilled by different farmers who operate under different age, sex and farming-time constraints. In general, young farmers can manage more cropland area than old farmers, and male farmers can manage more cropland area than female farmers; these differences are particularly apparent in mountainous regions. In addition, full-time farmers farm more cropland than part-time farmers. Diverse farming ability due to the differing age, sex and farming effort need to be converted into a standard farming ability so that they can be compared among different regions.

We set the conversion coefficients (CC) of age and sex with reference to the work-point calculation norms in the people's commune period (1960s) in China and empirical analysis (Lin et al. 2012). A male farmer's sex $\mathrm{CC}$ is 1 , and a female farmer's sex CC is 0.8 . A young farmer's age $\mathrm{CC}$ is 1 , and an elderly farmer's age CC of is 0.5 . For farming time (time spent on agricultural work), $\mathrm{CC}$ is inferred based on household data from RPOSS. The average farming time input is about 12 to 16 days per mu, and the average household farming time is half the total average household agriculture time, which means one standard labourer's agriculture time in a year is about 30 days (S2). Therefore, if one labourer's agriculture time in a year is larger than one month, his/her CC of farming time is 1 ; otherwise it is 0.5 . Multiplying the three CCs, we derive overall-CCs for different groups of labour forces; these are listed in Table 2. It is important to note that $C A P A L$ in this study is the cultivated area per standard labourer.

(3) Conversion of Customary-mu to Standard-mu. Standard-mu is the area unit measured by field measurement. One standard is equal to $666.67 \mathrm{~m}^{2}$ or $1 / 15$ hectare. Cropland areas in China are measured in so-called "customary-mu" (also named "large-mu"), an area unit based on a local custom of measurement. It accounts for soil quality, terrain, and farming time input (Hong, 2007; Wang et al., 2008). Different regions 
have different measurements, which correspond with local conditions, but a customary mu is always larger than the standard mu (1.1-2 times larger). Croplands in some regions (e.g., mountainous regions) yield less than croplands in other regions (e.g., plains areas), and need more labour input, so the customary-mu is an easier unit for determining rent and communicating with farmers. In addition, the Chinese government also implicitly accepts this because it is good for reporting, indicating high per unit yield. We define the custom-to-standard (CTS) coefficient for each province using the field survey of mountainous areas in 2015 to 2016 and data from relevant literature and expertise (Table 3). Because we have no survey data for Xinjiang, Tibet, their Custom-to-standard coefficient is estimated as 1.

\section{Projection of population and agricultural labour force}

In this study, demographic changes and agricultural labour force changes (not only the size, but also the age and gender structure) are key factors affecting the extent of cropland abandonment. A more elaborate way to project agricultural labour force is necessary. IIASA-PDE provides an elaborate and effective way to project population and subsequent agricultural labour forces. Below are the calculation procedures for this method in mountainous counties by age group and sex.

(1) National population projection method. Here, we will complete the multi-state rural and urban population projection simultaneously using the PDE model. Although we only need the rural population projection, the urban population projection has a very close relationship with the rural due to the massive rural-urban migration in China. Thus, the urban rate is a useful indicator for examining the rationality of the projections.

(2) Provincial population projections. We modify the decomposition method of Toth (Toth et al., 2003) for the provincial decomposition of rural population projections. Equations (3), (4) and (5) show the modified method for decomposition.

$$
\bar{P}_{i, 1, k}^{m / f}=b_{i} \times \sum_{j=1}^{18} p_{i, j, k-5}^{m / f} \times \frac{s_{1, k}^{m / f}}{\sum_{i}^{31}\left[b_{i} \times \sum_{j=1}^{18} p_{i, j, k-5}^{m / f}\right]} \quad i=1, \ldots, 31, \quad j=1, \ldots, 18, k=2010, \ldots, 2030
$$

Where: $i$ represents the number of provinces from 1 to $31 ; j$ represents the 5 -year age group from $0-4$ to over $85 ; k$ represents years.

$\bar{P}_{i, 1, k}^{m / f}=$ male/female population in province $\mathrm{i}$, age group $0-4$, year k

$p_{i, j, k-5}^{m / f}=$ male/female population in province $\mathrm{i}$, age group $\mathrm{j}$ year $\mathrm{k}-5$

$b_{i}=$ birth rate by sex in province $\mathrm{i}$, year 2010

$s_{1, k}^{m / f}=$ projected national rural male/female population in age group $0-4$, year $\mathrm{k}$

$\bar{P}_{i, j, k}^{m / f}=\left(1-d_{i, j-1}^{m / f}\right) \times p_{i, j-1, k-5}^{m / f} \times \frac{s_{j, k}^{m / f}}{\sum_{i} p_{i, j-1, k-5}^{m / f}} \quad i=1, \ldots, 31, \quad j=2, \ldots, 18, k=2010, \ldots, 2030$

Where: $\bar{P}_{i, j, k}^{m / f}=$ male/female population in province $\mathrm{i}$, age group $\mathrm{j}$, year $\mathrm{k}$

$p_{i, j-1, k-5}^{m / f}=$ male/female population in province $\mathrm{i}$, age group $\mathrm{j}-1$, year $\mathrm{k}-5$

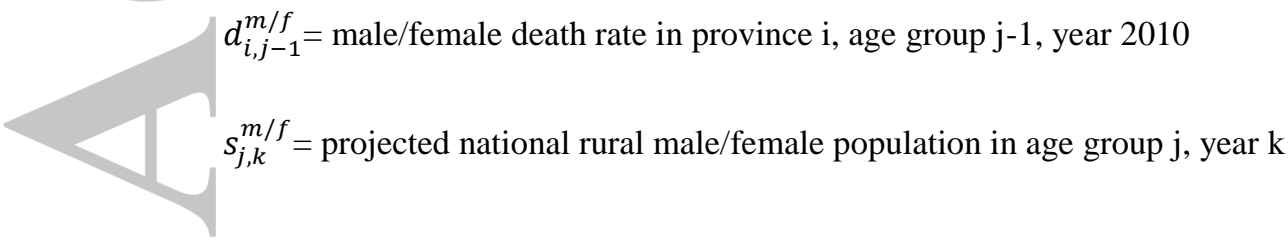




$$
\hat{P}_{t, j, k}^{m / f}=\left(1-h_{i, j-1}^{m / f}\right) \times \bar{p}_{i, j-1, k-5}^{m / f} \times \frac{s_{j, k}^{m / f}}{\sum_{i} \bar{p}_{i, j-1, k-5}^{m / f}} \quad i=1, \ldots, 31, j=2, \ldots, 18, k=2010, \ldots, 2030
$$

Where: $\hat{P}_{t, j, k}^{m / f}=$ male/female population after migration in province $\mathrm{i}$, age group $\mathrm{j}$, year $\mathrm{k}$ $h_{i, j-1}^{m / f}=$ male/female out migration rate in province $\mathrm{i}$, age group $\mathrm{j}-1$, year 2010 $\bar{p}_{i, j-1, k-5}^{m / f}=$ male/female population before migration in province $\mathrm{i}$, age group $\mathrm{j}-1$, year $\mathrm{k}-5$ $s_{j, k}^{m / f}=$ projected national rural male/female population in age group $\mathrm{j}$, year $\mathrm{k}$

After the provincial decomposition, we regroup the result using three large age groups (0-14, 15-59, over 60 ) and sex for the next step, resulting in each projection divided into six groups.

(3) Extraction of population projection in mountainous counties. In mountainous counties, the proportion of total provincial population taken by each group will not remain stable at all time. Based on census data in 2000 and 2010, we calculated the proportions in mountainous counties for each province in 2000 and 2010, and we use the rate of change during the decade to project proportional changes in mountainous counties in the future.

(4) Calculation of rural labour force and agricultural labour force. With reference to the household data from RPOSS and China Statistics Yearbook, we defined the labour participation rate for the six groups, and set their proportional value of agricultural labour force according to the trend analysis and the household data from RPOSS. With consideration of the low threshold (30 days per year) for a full-time labourer, this threshold between part-time and full-time was assumed to remain the same as 2010 .

\section{Scenario setting for PDE model}

Considering the death rate in China is already low and will only lower in the future, we assumed the death rate would remain stable for the next 20 years. Meanwhile, total fertility rate (TFR) will likely change significantly because of the new tow-child policy. Rural-to-urban migration was assumes constant, and high due to the Chinese national new urbanization strategy (Table 4).

We validated projected results from the PDE model by comparing the projected urban rate and the government planned urban rate (S3). The projected urban rates matched well with the planned values, and both will reach around $70 \%$ in 2030.

\section{Scenario setting for CAPAL model}

As mentioned earlier, APFAPL, APS, DAPL, Land rental rate, PPF, FCINDEX and MCI have significant influence on $C A P A L$. While APS is the most influential factor on $C A P A L$, it is hard to increase because of the rough mountainous terrain in these regions. Considering DAPL, Land rental rate PPF, FCINDEX and MCI likely not change too much. APFAPL is the most moveable variable in the future, and becomes a more and more important explanatory variable for CAPAL; we employed three different APFAPL growth rates to explore different scenarios. As the growth rate of APFAPL in mountainous regions has been lower than in plains areas, we calculated the historic APFAPL growth for each province, including mountainous and plains areas, based on data from 2000 to 2010 and then we formulated three scenarios. In Scenario 1, APFAPL in mountainous counties was set to 0, in Scenario 2, the APFAPL growth rate in mountainous counties was set to half the provincial historic trend, and in Scenario 3, the APFAPL growth rate in mountainous counties was set equal to 
the provincial historic trend.

\section{Material}

Household survey data

Household survey data for this study was derived from RPOSS, which have been running for 28 years under the management of the Research Centre for Rural Economy, Chinese Ministry of Agriculture. RPOSS has been updating the data once a year at both the village and household level. The survey involves 23 thousand households and 360 administrative villages, and covers 31 provinces in the Chinese mainland. Its contents are exhaustive and comprehensive, including household population, labour, land use, sales, income, fixed assets, expenditure, and food consumption, and have been used widely in China's rural and agricultural research (Hu \& Zhong, 2013; Qin et al., 2012). Permanent observation sites mean the surveyed villages and households are fixed, but not absolutely fixed. Some old surveyed villages and households are partial substituted by other new ones at random. Survey villages have been classified in three types in terms of topography: mountainous village, hilly village and plain village. In this study, we primarily use the data from mountainous villages.

\section{Land use data}

The national cropland map was extracted from the remotely sensed data WESTDC taken in 2000, and provided by the China Data Sharing Infrastructure of Earth System Sciences from the website http://www.geodata.cn/. WESTDC-2000 is the aggregated results of GLC2000-China, IGBPDIS, MODIS-China, UMD-China, and China Land-use Map in 2000 (scale 1:100000) from the Chinese Academy of Sciences. The resolution of WESTDC is $1 \mathrm{~km}$, meaning the area proportion of each land-use and land-cover type is in a $1 \mathrm{~km}$ grid. WESTDC has 25 types of land-use and land-cover, among them paddy field and rainfed cropland belong to cropland, so we calculated the sum of these two types' area proportion. We then multiplied the area proportion of cropland in each $1 \mathrm{~km}$ grid by the area of the $1 \mathrm{~km}$ grid to obtain the cropland area in each $1 \mathrm{~km}$ grid. However, this cropland area is a gross area, which includes cropland and ridges, irrigation canals, farming roads. Therefore, the area was converted to net area using a conversion coefficient of gross area to net area of 0.761 (Liu, et al., 2005).

Demographic data and Agricultural labour force data

Demographic data include Chinese national census data (percent sampling survey) by county in 2000 and 2010 , and population data using a 2005 one percent sampling provincial survey.

Topographic data

The national DEM was obtained from the SRTM digital elevation data produced by NASA SRTM-DEM, updated to Version 4. National slope data was obtained by DEM processing in ArcGIS 10.0. The resolution is $90 \mathrm{~m}$ for both sets of topographic data. 


\section{Results}

\section{Results of regression model}

The values of CAPAL, APS, APFAPL, DAPL, FCINDEX, PPF, MCI and Land rental rate were compiled from RPOSS household data. Sample variable periods are from 2003-2010. There are 859 total observations. All variables passed the multi-collinearity test with VIF ranging from 1.12 to 4.12. According to RPOSS, although some villages and households are fixed for some years, they vary over time, because some old villages were replaced by new villages and residents moved. Thus, strictly speaking, the data is not panel data. We employed a multiple regression model run by Stata 12.0 .

The results show that $A P F A P L, D A P L, A P S$, Land rental rate, PPF and D2 are positive and statistically significant at the 5\% level, while FCINDEX, MCI,D4,D6 and D7 are negative and statistically significant at the $5 \%$ level, which confirms our expectation (Table 5). The adjusted R-squared is 0.84 , which is high enough for further estimation. According to the regression result, we built up a model for $C A P A L$ estimation:

$$
\begin{aligned}
C A P A L=0.7671 & +0.0002 \times A P F A P L+2.0154 \times D A P L+2.0370 \times A P S-0.0082 \times F C I N D E X \\
& +0.0234 \times L R R-0.1227 \times M C I+0.4889 \times P P F+0.6584 \times D 1+0.6797 \times D 2 \\
& -0.1094 \times D 3-1.2238 \times D 4+0.0700 \times D 5-0.7043 \times D 6-0.4946 \times D 7-0.4024 \\
& \times D 8
\end{aligned}
$$

We used the equation (6) to estimated $C A P A L$ at provincial level, and the goodness of fit is $0.89(P<0.01)$, indicating the regression model is reliable for estimating $C A P A L$ at provincial level.

Current extent of cropland abandonment

The CAPAL estimation should be based at the provincial level due to data limitations. For independent variables, such as $A P S, D A P L$, Land rental rate, their provincial (only mountainous counties) values are represented by the mean of the surveyed mountainous villages' values. The APFAPL and $M C I$ values by province were derived from the China Statistics Yearbook. The values of FCINDEX and PPF were obtained from land use data from WESTDC-2000.

The estimation results show that total area of abandoned croplands (include cropland returned to forest and grassland) in mountainous counties is 147.1 million mu for the period from 2000 to 2010, which means $27.7 \%$ of cropland in mountainous counties was abandoned and revegetated during the decade. Current abandoned croplands are mainly distributed in southwest China (Figure 4), with the most complex topography in China. North China, especially Hebei, Ningxia, Henan and Gansu Province, also have large areas of abandoned cropland. In the mountainous counties of Sichuan, Gansu, Ningxia, Hebei and Guizhou, abandoned cropland accounts for $46 \%$ of total cropland. The abandoned rates of six provinces have already surpassed $40 \%$. As there are no mountainous counties in Jiangsu Province, Tianjin and Shanghai City, these province-level regions were not included in the estimation. The abandoned rates for Xinjiang and Tibet were estimated at 0 because of their abundant agricultural labour forces. 


\section{Agricultural Labour Force Projection}

The size of the original agricultural labour force, before the conversion of standard agricultural labour force, in mountainous counties will likely decline from 93 million to 42 million during the period 2010 to 2030 (S4). The corresponding size of the standard agricultural labour force in mountainous counties will likely shrink from 72 million to 27 million during these 20 years. The percent decrease in standard agricultural labour force is $62 \%$, whereas the percent decrease in the original labour force is $54 \%$, highlighting the rapid ageing of the agricultural labour force in rural areas of mountainous counties.

Future Cropland Abandonment

According to projections for agricultural labour forces based on the PDE model, the total abandoned croplands in mountainous counties may reach 261 to 350 million mu in 2030 (Figure 5); meanwhile, the abandoned rate may increase to more than $49 \%$ to $66 \%$ in 2030 , indicating only one third of cropland would be cultivated in the most extreme case.

\section{Discussion}

The estimation method and its reliability

In this study, we employed a new method to estimate and predict the extent of cropland abandonment without using remote sensing techniques. Our estimated result shows that cropland abandonment has been very common in the mountainous regions of China. Around $28 \%$ is considerable, but GGP may have been the main driver for cropland abandonment during the decade 2000 to 2010. According to China's State Forestry Administration, 139 million mu of croplands were returned to forest and grassland from 1999 to 2009. Because we cannot obtain the GGP area by county, we calculated the area proportion of GGP returned cropland to total cropland from RPOSS, and obtained a value of $14.9 \%$; this suggests the abandoned rate (by farmer) could have been $12.8 \%$ in 2010.

We validated the regression model by comparing the fitted abandoned rate and actual abandoned rate from three mountainous counties in Chongqing (S5), located in southwest China. Actual abandonment rates were from remote sensing data for Youyang and Wushan County in 2010 and household survey data. The latter was for Wulong County, with independent households surveyed by ourselves in 2012; fitted abandonment rates were estimated based on national census data in 2010. Average error (absolute error) for the three counties is $6 \%$. Overall, the multiple regression model provides a good estimation for further estimation, although we only have three values for validation. Furthermore, we employed the NDVI data to test the reliability of our method for the provincial estimation of cropland abandonment. As the restoration of vegetation after cropland abandonment is expected to increase the NDVI, there is a theoretically positive relationship between the extent of cropland abandonment and NDVI change rate. Considering that the restoration usually takes several years, we calculated the slope value of NDVI (only in cropland areas of mountainous counties) from 2000 to 2013 at provincial level and analysed its correlation with the estimated abandoned rate (S6). The spearman correlation coefficient is 0.66 $(P<0.01)$, proving the reliability of our method to some extent.

Another individual national survey (covering 29 provinces and 262 counties in China) by CHFS reported that $15 \%$ of rural area farmland was idle, including abandonment and fallow, in 2013, an increase from $13.5 \%$ in 2011 (CHFS, 2014). It is no doubt farmland abandonment is significantly more common in mountainous area than in plains area ( $\mathrm{Li} \& \mathrm{Li}, 2016$; Mather \& Needle, 1998) because farming costs are much higher for mountainous cropland due to unfavourable cultivation conditions, so the cropland abandoned rate increases with 
elevation and slope (Shao et al., 2015). However, because the CHFS result includes fallow cropland, the abandoned rate is likely to be less than $13.5 \%$. Thus, our estimation for the period from 2000 to 2010 closely matches the CHFS survey result, indicating that croplands in mountainous regions are under higher risk of abandonment.

\section{Policy implication}

The Chinese government has put forward "farmland red line", which means farmland should have been maintained to at least 1.8 billion mu from as early as 2007 , in order to ensure national food security. Since then, "defend farmland red line" had been emphasized repeatedly by the government (Cui \& Kattumuri, 2011). In order to halt the decline in cultivated, land Requisition-compensation balance, also known as maintaining a dynamic balance of cultivated land, is a very important provision of the "Land management law of China" initiated in 1996 (Zou, 1997). It means farmland occupied by construction land must be replenished by reclaiming the same area of land. However, because almost all flat land has been reclaimed as cropland, newly reclaimed farmland is usually located in hilly and mountainous regions and arid regions, where ecosystems are fragile, land quality is poor ( $\mathrm{Li}$ et al., 2016; Xin et al., 2009; Yang \& Li, 2000), and cultivation conditions are unfavourable. This has resulted into the contradictory concurrence of cropland reclamation and abandonment in the same hilly and mountainous regions, as well as ecological hazards. The Second National Land and Resources Survey reported that cropland in 2009 is 2.03 billion mu in China mainland. According to our projection of cropland abandonment in mountainous counties, in the worst case, about 203 million mu of cropland may be abandoned from 2010 to 2030 . This would decrease the area of cropland to 1.83 billon hectares, which almost reaches China's farmland red line. This could exacerbate future challenges in maintaining China's food security. As a consequence, it is not economically feasible to rely on reclamation in ecologically fragile areas to balance the quantity of China's cultivated land (Yang \& Li, 2000). It would be better to transfer reclamation financial resources to prevention of cropland abandonment in mountainous area, rather than reclaiming land with high cost in hilly and mountainous areas.

China's GGP (also known as Sloped Land Conversion Programme) was the largest conservation program in the developing world. The GGP was implemented in 25 provinces in 1999 and restarted in 2014 with the purpose of mitigating the risk of more frequent and severe hazards (e.g., water and soil erosion, flood and drought) and ecological degradation and deforestation (Liu \& Wu, 2010), which have been attributed to over-cultivation of sloping land and sharp decline in natural forests (Zhang et al., 2000). The artificial revegetation of sloping land (greater than 25 degrees in South China and 15 degrees in North China) has significantly improved the environmental and ecological sustainability in these ecologically fragile areas, producing tremendous ecological benefits (Liu et al., 2008; Song et al., 2014), such as carbon sequestration (Ostwald et al., 2011; Song et al., 2012; Zhang et al., 2010), reduced soil erosion (Deng et al., 2012; Zhoua et al., 2009) and enhanced biodiversity. The "Forest scarcity path" is considered one of the pathways for China's forest transition, which was due to the GGP national reforestation policies and other reforestation projects (He $e t$ al., 2015; Lambin \& Meyfroid, 2010; Mather, 2007; Rudel et al., 2005). However, the sharp increase in labour wage resulted in the marginalization of sloping cropland (Li \& Zhao, 2011). We contrast the profits changes in corn production between plains and mountainous provinces from 2003 to 2013 to illustrate the marginalization of cropland in mountainous area. The profits from all 12 provinces in 2003 were larger than 0 , and the profits from mountainous province were even more than from plains provinces. All 12 provinces profit decreased in 2013. However, the profits from mountainous provinces in 2013 were reduced to zero and below, while profits 
from plains provinces decreased slightly and were still larger than 0 in 2013 (S7). Therefore, the forest transition in China may have transferred from a "forest scarcity path" to a "economic development path"; these two drivers have the equal contribution, which is evidenced by the survey in Chongqing. Accordingly, there was no need to restate GGP in 2014 for reforesting sloping cropland, because the marginal sloping-cropland would be abandoned and followed by natural vegetation restoration. The GGP should at least be tailored to the specific needs of different regions (Liu \& Wu, 2010).

\section{Mitigation strategies for cropland abandonment in mountainous regions}

The CAPAL Regression model in this study indicated that the increase in APL, APFAPL, DAPL and Land rental rate are in favour of alleviating cropland abandonment. The increase in APL, APFAPL and DAPL can improve farmers' farming ability. An active land lease market may alleviate the abandonment to some extent because marginal croplands are available to households with ample labour, so thus negating some cropland abandonment (Shao et al., 2015; Zhang et al., 2014a). Nevertheless, improving the rural land rental market can only alleviate or postpone cropland abandonment, but not eradicate it. Our results indicated that the crucial measure is improving labour productivity $(C A P A L)$ in mountainous cropland to narrow the gap with mechanized-farming cropland in the plains and prevent the marginalization of mountainous cropland. Mean elasticity analysis indicates that APS (elasticity at mean is 0.72) is the most influential CAPAL factor, which means land consolidation in mountainous areas is the most effective solution for mitigating cropland abandonment. Thus, land consolidation in mountainous areas may be a more effective measure to defend the "1.8 billion mu cropland red line" than reclamation; the Chinese government should invest more on land consolidation projects in mountainous regions with the purpose of reducing cropland abandonment. Although APFAPL's impact on $C A P A L$ is less than $A P L$, elasticity at the mean is 0.04 , the large $A P F A P L$ input can also effectively alleviate cropland abandonment (Shao et al., 2015).

\section{A glimpse of future abandonment}

Aging agricultural labour forces is also a sizable driver of cropland abandonment in mountainous regions by shrinking the size of the agricultural labour force. The proportion of aging farmers will rise to $50 \%$ in 2030 from $20 \%$ in 2010 . The average growth rate of the aging farmers share is $1.5 \%$ during the period 2010 to 2030 , three times larger than the historic trend (2003 to 2010, household data from RPOSS). Because agricultural labour forces aging has an undesirable effect on cultivation in areas of low level agricultural mechanization (Hu \& Zhong, 2013), an accelerating aging is bound to precipitate expansion of cropland abandonment. China is still in the process of fast urbanization; rapid migration and aging of agricultural labour forces is inevitable in the near future (Lu \& Yang, 2012). The Chinese government has adopted a series of measures to support development of agriculture, including remitting agricultural taxes, increasing agricultural subsidies, and raising grain prices. These supportive measures are not strong enough to mitigate cropland marginalization and abandonment on account of the sizable rural-to-urban migration of the rural population from mountainous regions (Ding et al., 2009). The extent of cropland abandonment will continue to grow fast under the context of rapid urbanization (Shao et al., 2015), requiring the government to make a more positive response regarding mechanism in the context of cropland abandonment (Xie et al., 2014).

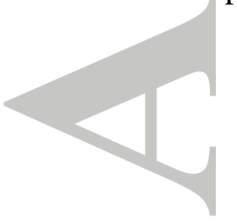




\section{Limitations and future work}

Due to the lack of household survey data, we could only carry out the provincial estimation of cropland abandonment. However, it is a matter of great concern to us to understand where the risk of farmland abandonment is higher. In the future, we plan to carry out an extensive survey of farmland abandonment in mountainous regions to study the key influencing factors of farmland abandonment. Base on the analysis of influencing factors, combined with remote sensing data, DEM and socio-economic factors, we would try to build the risk evaluation model of farmland abandonment at finer level, in order to provide more applicable references for agricultural policy making of mountainous areas.

\section{Conclusion}

This study developed a novel method to estimate the extent of cropland abandonment in mountainous regions. Compared with remote sensing technique, the new method is applicable and efficient in large-scale estimations, and is able to predict future trajectory. This study shows that 26 of 31 provinces are encountering cropland abandonment of mountainous areas. The national abandoned rate in mountainous counties reached $28 \%$ in 2010, including reforested croplands from the Grain for Green Programme. Projection of agricultural labour forces based on a PDE model indicated a sharp decline and aging trend of agricultural labour forces in mountainous areas. Consequentially, a sizeable extent, 114 to 203 million mu, of croplands may be abandoned between 2010 and 2030, which could significantly exacerbate the future challenges of maintaining China's food security. The multiple regression model results revealed that the average plot size, agricultural productive fixed assets per labourer, farm cattle per labourer, and land rental rate have a positive and significant impact on cultivated area per labourer. As a result, a substantial investment increase in land consolidation projects and agricultural productive fixed assets could help mitigate the risk of cropland abandonment. However, some current policies have not taken full account of extensive cropland abandonment, which may lead to inefficiencies in these policies.

\section{Acknowledgement}

This study is part of an International Cooperation and Exchanges project between NSFC-IIASA, "Efficiency and security of land resource management under rapid agricultural land use transformation and increasing interactions between urban-rural processes in China: Case studies in Chongqing", and is financed by the National Natural Science Foundation of China (Grant no. 41161140352). We particularly wish to thank the Office of Rural Permanent Observation Sites Survey for providing household survey data and their assistance during data processing. We also acknowledge data support from the "National Earth System Science Data Sharing Infrastructure, National Science \& Technology Infrastructure of China (http://www.geodata.cn)".

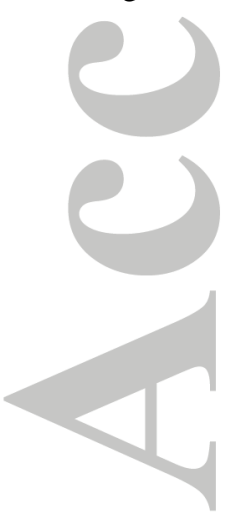




\section{References}

Alcantara C, Kuemmerle T, Baumann M, Bragina EV, Griffiths P, Hostert P, Knorn J, Müller D, Prishchepov, AV, Schierhorn F, Sieber A, Radeloff VC. 2013. Mapping the extent of abandoned farmland in Central and Eastern Europe using MODIS time series satellite data. Environmental Research Letters 8: 1-9. Doi: 10.1088/1748-9326/8/3/035035

Alcantara C, Kuemmerle T, Prishchepov AV, Radeloff VC. 2012. Mapping abandoned agriculture with multi-temporal MODIS satellite data. Remote Sensing of Environment 124: 334-347. Doi: 10.1016/j.rse.2012.05.019

Barbier EB, Burgess JC, Grainger A. 2010. The forest transition Towards a more comprehensive theoretical framework. Land Use Policy 27: 98-107. Doi:10.1016/j.landusepol.2009.02.001

Benayas JMR, Martins A, Nicolau JM, Schulz JJ. 2007. Abandonment of agricultural land: An overview of drivers and consequences. CAB Reviews: Perspectives in Agriculture, Veterinary Science, Nutrition and Natural Resources 2: 1-12. Doi: 10.1079/PAVSNNR20072057

Bentley J. 1997. Economic and ecological approaches to land fragmentation: in defense of a much maligned phenomenon. Annual Review of Anthropology 16: 31-67. DOI: 10.1146/annurev.an.16.100187.000335

Cerda A. 1997. Soil erosion after land abandonment in a semiarid environment of southeastern Spain. Arid Soil Research and Rehabilitation 11: 163-176. Doi: 10.1080/15324989709381469

Chen YQ, Li XB. 2009. Structural change of agricultural land use intensity and its regional disparity in China. Acta Geographica Sinica 64: 469-478. Doi: 10.1007/s11442-009-0545-7

Chen N, Yang WN, Li J. 2012. Distribution characteristics of landuse patterns at terrain gradients in hills and mountainous of Bazhong City. Bulletin of Soil and Water Conservation 32: 185-188. Doi: 1000-288X(2012)01-0185-04

Cheng W. 2011. Study on the Remote Sensing Methods of Surveying Abandoned Farmland in the South, Institute of Remote Sensing Applications. Chinese Academy of Sciences, Beijing.

CHFS. 2014. Research report of China household finance survey 2014. Survey and Research Center for China Household Finance.

Ciaian P, Swinnen JFM. 2009. Credit market imperfections and the distributionof policy rents American. Journal of Agricultural Economics 91: 1124-1139. Doi: 10.1111/j.1467-8276.2009.01311.x

Cohen M, Varga D, Vila J, Barrassaud E. 2011. A multi-scale and multi-disciplinary approach to monitor landscape dynamics: a case study in the Catalan pre-Pyrenees (Spain). The Geographical Journal 177: 79-91. Doi: $10.1111 / \mathrm{j} .1475-4959.2010 .00368 . \mathrm{x}$

Corbelle-Rico E, Crecente-Maseda R, Santé-Riveira I. 2012. Multi-scale assessment and spatial modelling of agricultural land abandonment in a European peripheral region Galicia (Spain), 1956-2004. Land Use Policy 29: 493-501. Doi:10.1016/j.landusepol.2011.08.008

Cramer VA, Hobbs RJ, Standish RJ. 2008. What's new about old fields? Land abandonment and ecosystem assembly. Trends in Ecology and Evolution 23: 104-112. Doi:10.1016/j.tree.2007.10.005

CSY. 2014. China Statistical Yearbook. China Statistical Publishing House, Beijing.

Cui S, Kattumuri R. 2011. Cultivated Land Conversion in China and the Potential for Food Security and Sustainability. Asia Research Centre Working Paper 35.

Deininger K, Jin S. 2009. Land rental markets in the process of rural structural transformation: productivity and equity impacts in China. Journal of Comparative Economics 37: 629-646. Doi: 10.1016/j.jce.2009.04.005

Deng L, Shangguan ZP, Li R. 2012. Effects of the grain-for-green program on soil erosion in China. International Journal of Sediment Research 27: 131-138. Doi: 10.1016/S1001-6279(12)60021-3

Ding GP, Liu CW, Huang LN. 2009. A theoretical analysis and empirical research of marginalization of agricultural land in hilly-mountainous area under farmer-benefiting policy: a case study of Tongcheng County in Hubei Province. Geographical Research 28: 109-117. DOI: 10.11821/yj2009010013

Doorn AMV, Bakker MM. 2007. The destination of arable land in a marginal agricultural landscape in South Portugal: An exploration of land use change determinants. Landscape Ecology 22: 1073-1087. DOI: 10.1007/s10980-007-9093-7

Elbakidze M, Angelstam P. 2007. Implementing sustainable forest management in Ukraine's Carpathian Mountains: the role of traditional village systems. Forest Ecology and Management 249: 28-38. Doi: 10.1016/j.foreco.2007.04.003

Ellis F. 2006. Peasant economics: Farm households and agrarian development. Shanghai People's Publishing House, Shanghai.

EU. 2004. Land abandonment and biodiversity in relation to the 1st and 2nd pillar of the EU's commonagricultural policy, in: outcome of an international seminar in Sigulda, L. (Ed.), 21-30.

Fan S, Chan-Kang C. 2005. Is small beautiful? Farm size, productivity, and poverty in Asian agriculture. Agricultural economics 32: 135-146. Doi: 10.1111/j.0169-5150.2004.00019.x

Fan S, Zhang X. 2002. Production and productivity growth in Chinese agriculture: new national and regional measures. Economic Development and Cultural Change 50: 819-839. DOI: $10.1086 / 343136$

Gellrich M, Baur P, Koch B, Zimmermann NE. 2007. Agricultural land abandonment and natural forest re-growth in the Swiss mountains: a spatially explicit economic analysis. Agriculture, Ecosystems \& Environment 118, 93-108. Doi: 10.1016/j.agee.2006.05.001

Gellrich M, Zimmermann NE. 2007. Investigating the regional-scale pattern of agricultural land abandonment in the Swiss mountains: a spatial statistical modelling approach. Landscape and Urban Planning 79: 65-76. Doi:10.1016/j.landurbplan.2006.03.004

Grainger A. 1995. The forest transition: an alternative approach. Area 27: 242-251.

Guerschman JP, Paruelo JM, Bella CD, Giallorenzi MC, Pacin F. 2003. Land cover classification in the Argentine Pampas using multi-temporal Landsat TM data. International Journal of Remote Sensing 24: 3381-3402. Doi: $10.1080 / 0143116021000021288$

Hayami Y, Ruttan VW. 1971. Agricultural development: An international perspective. Johns Hopkins, Baltimore. 
He F, Li S, Zhang X. 2015. A spatially explicit reconstruction of forest cover in China over 1700-2000. Global and Planetary Change 131,73-81. DOI: 10.1016/j.gloplacha.2015.05.008

Hong MY. 2007. Custom proto-institution of agricultural land and the implementation mechanism. HoHai University, Nanjing.

Hu XZ, Zhong FN. 2013. The impact of population aging on planting production: based on the analysis of the two crops of wheat and cotton. Issues in Agricultural Economy 2:36-43. Doi:10.13246/j.cnki.iae.2013.02.007

Izquierdo AE, Angelo, CDD, Aide TM. 2008. Thirty years of human demography and land-use change in the Atlantic Forest of Misiones, Argentina: an evaluation of the forest transition model. Ecology and Society 13: art 3.

Izquierdo AE, Grau HR. 2009. Agriculture adjustment, land-use transition and protected areas in Northwestern Argentina. Journal of Environmental Management 90: 858-865. Doi: 10.1016/j.jenvman.2008.02.013

Jiang XB, Zeng HC. 2009. Quantifying mountain regions of China: a case study in Sichuan. Journal of Mountain Science 27: 25-27.

Keenleyside C, Tucker GM. 2010. Farmland abandonment in the EU: an assessment of trends and prospects, in: Report prepared for WWF. Institute for European Environmental Policy, L. (Ed.).

Khanal NR, Watanabe T. 2006. Abandonment of agricultural land and its consequences: a case study in the Sikles Area, Gandaki Basin, Nepal Himalaya. Mountain Research and Development 26: 32-40. Doi: 10.1079/PAVSNNR20072057

Kuang YQ, Huang NS, Hu ZY. 2002. Analysis on the deviation of the farm land area estimate reported in statistics of the prefecture grade cities in Guangdong Province. Scientia Geographica Sinica 22: $730-735$. Doi: 100-0690(2002)06-0730-06

Kuemmerle T, Hostert P, Radeloff VC, van der Linden S, Perzanowski K, Kruhlov I. 2008. Cross-border comparison of post-socialist farmland abandonment in the Carpathians. Ecosystems 11: 614-628. Doi: 10.1007/s10021-008-9146-Z

Lambin EF, Meyfroid P. 2010. Land use transitions Socio-ecological feedback versus socio-economic change. Land Use Policy 27: 108-118. Doi: 10.1016/j.landusepol.2009.09.003

Lasanta T, Vicente-Serrano SM. 2012. Complex land cover change processes in semiarid Mediterranean regions: an approach using Landsat images in northeast Spain. Remote Sensing of Environment 124: 1-14. Doi: $10.1016 / \mathrm{j} . \mathrm{rse} .2012 .04 .023$

Lemel H. 2000. Rural property and economy in post-communist Albania. Berhghahn books, New York.

Li SF, Dong YX. 2013. Vertical hierarchical model of urban land use and the progress of evolvement in Guangzhou. Journal of Natural Resources 28: 1019-1029. Doi: 1000-3037(2013)

Li SF, Li XB. 2017. Global understanding of farmland abandonment: A review and prospects. Journal of Geographical Sciences 27: 1123-1150. DOI: 10.1007/s11442-017-1426-0

Li XB, Zhao YL. 2011. Forest transition, agricultural land marginalization and ecological restoration. China Population, Resources And Environment 21: 91-95.

Li S, He F, Zhang X. 2016. A spatially explicit reconstruction of cropland cover in China from 1661 to 1996. Regional Environmental Change 16: 417-428. DOI: 10.1007/s10113-014-0751-4

Liao HL. 2005. The estimation of hosehold rice production function in rice-growing areas of China. Chinese Rural Economy 6: $11-18$.

Lin BX, Deng HS. 2012. The impact of agricultural aging on land use efficiency: a case study of Zhejiang province. Chinese Rural Economy 4: 15-25.

Liu C, Wu B. 2010. 'Grain for Green Programme' in China: policy making and implementtation. Chian Policy Institute, The University of Nottingham.

Liu J, Liu M, Tian H, Zhuang D, Zhang Z, Zhang W, Tang X, Deng X. 2005. Spatial and temporal patterns of China's cropland during 1990-2000: an analysis based on Landsat TM data. Remote Sensing of Environment, 98: 442-456. Doi: 10.1016/j.rse.2005.08.012

Liu J, Li S, Ouyang Z, Tam C, Chen X. 2008. Ecological and socioeconomic effects of China's policies for ecosystem services. Proceeding of the National Academy of Sciences of Unite States of America 105: 9477-9482. Doi: 10.1073/pnas.0706436105

Liu JY, Kuang WH, Zhang ZX, Xu XL, Qin YW, Nin J, Zhou WS, Zhang SW, Li RD, Yan CZ, Wu SX, Shi XZ, Jiang N, $\mathrm{Yu}$ DS, Pan XZ, Chi WF. 2014. Spatiotemporal characteristics, patterns and causes of land use changes in China since the late 1980s. Acta Geographica Sinica 69: 03-14. Doi: 10.1007/s11442-014-1082-6

Liu JY, Zhang ZX, Xu XL, Kuang WH, Zhou WC, Zhang SW, Li RD, Yan CZ, Yu DS, Wu SX, Jiang N. 2009. Spatial patterns and driving forces of land use change in China in the early 21st century. Acta Geographica Sinica 64: 1411-1420. Doi: 10.1007/s11442-010-0483-4

Liu JY, Zhang ZX, Zhuang DF, Wang, YM, Zhou WC, Zhang SW, Li RD, Jiang N, Wu SX. 2003. A study on the spatial-temporal dynamic changes of land-use and driving forces an alyses of Chinain the 1990s. Geographical Research 22: 1-22. Doi: $10.11821 / y j 2003010001$

Lu F, Yang YW. 2012. Measurement of factors behind the decline of the agricultural labour share in total labour force of China (1990-2030). Chinese Journal of Population Science 4:13-24.

MacDonald D, Crabtree JR, Wiesinger G, Dax T, Stamou N, Fleury P, Gutierrez Lazpita J, Gibon A. 2000. Agricultural abandonment in mountain areas of Europe: environmental consequences and policy response. Journal of Environmental Management 59: 47-69. Doi: 10.1006/jema.1999.0335

Mao P, Xu J, He X, Zhou Y. 2015. Transfer of land and increase of farmers' labour productivity: theoretical and empirical analysis. Economic Research Journal 11: 161-176.

Mather AS. 1992. The forest transition. Aera 24: 367-379.

Mather AS. 2007. Recent Asian forest transitions in relation to foresttransition theory. International Forestry Review 9 : 491-502. Doi: 10.1505/ifor.9.1.491

Mather AS, Needle CL. 1998. The forest transition a theoretical basis. Area 30: 117-124. Doi: 10.1111/j.1475-4762.1998.tb00055.x 
Melendez-Pastor I, Hernández EI, Navarro-Pedreño J, Gómez I. 2014. Socioeconomic factors influencing land cover changes in rural areas: the case of the Sierra de Albarracín (Spain). Applied Geography 52: 34-45. Doi: 10.1016/j.apgeog.2014.04.013

Milenov P, Vassilev V, Vassileva A, Radkov R, Samoungi V, Dimitrov Z, Vichev N. 2014. Monitoring of the risk of farmland abandonment as an efficient tool to assess the environmental and socio-economic impact of the Common Agriculture Policy. International Journal of Applied Earth Observation and Geoinformation 32: 218-227. Doi: 10.1016/j.jag.2014.03.013

Moravec J, Zemeckis R. 2007. Cross compliance and land abandonment. A research paper of the Cross-Compliance Network (Contract of the European Community's Sixth Framework Programme, SSPE-CT-2005-022727), Deliverable D17 of the Cross-Compliance Network.

Mottet A, Ladet S, Coqué N, Gibon A. 2006. Agricultural land-use change and its drivers in mountain landscapes: A case study in the Pyrenees. Agriculture, Ecosystems \& Environment 114: 296-310. Doi: 10.1016/j.agee.2005.11.017

Müller D, Leitão PJ, Sikor T. 2012. Comparing the determinants of cropland abandonment in Albania and Romania using boosted regression trees. Agricultural Systems 117: 66-77. Doi: 10.1016/j.agsy.2012.12.010

Nanni AS, Grau HR. 2014. Agricultural adjustment, population dynamics and forests redistribution in a subtropical watershed of NW Argentina. Regional Environmental Change 14: 1641-1649. Doi: 10.1007/s10113-014-0608-x

Oetter DR, Cohen WB, Berterretche M, Maiersperger TK, Kennedy RE. 2001. Land cover mapping in an agricultural setting using multiseasonal Thematic Mapper data. Remote Sensing of Environment 76: 139-155.

Ostwald M, Moberg J, Persson M, Xu J. 2011. The Chinese Grain for Green Program - assessing the sequestered carbon from the land reform. World Renewable Energy Congress, 2517-2522.

Ozdogan M, Woodcock, CE. 2006. Resolution dependent errors in remote sensing of cultivated areas. Remote Sensing of Environment 103: 203-217. Doi: 10.1016/j.rse.2006.04.004

Parés-Ramos IK, Gould WA, Aide TM. 2008. Agricultural abandonment, sub-urban growth, and forest expansion in Puerto Rico between 1991 and 2000. Ecology and Society 13. Doi: 10.5751/ES-02479-130201

Perz SG, Skole DL. 2003. Secondary Forest Expansion in the Brazilian Amazon and the Refinement of Forest Transition Theory. Society \& Natural Resources 16: 277-294. Doi: 10.1080/08941920390178856

Pointereau PF, Coulon PG, Lambotte M, Stuczynski T, Ortega VS, Rio AD. 2008. Analysis of farmland abandonment and the extent and location of agricultural areas that are actually abandoned or are in risk to be abandoned. Institute for Environment and Sustainability, Joint Research Centre, EC.

Price MF, Butt NE. 2000. Forests in sustainable mountain development report for 2000. CAB International Wallingford, UK: 4-9. DOI: 10.1007/1-4020-3508-X_52

Prishchepov AV, Radeloff VC, Dubinin M, Alcantara C. 2012. The effect of Landsat ETM/ETM+ image acquisition dates on the detection of agricultural land abandonment in Eastern Europe. Remote Sensing of Environment 126: 195-209. Doi: 10.1016/j.rse.2012.08.017

Pueyo Y, Beguería S. 2007. Modelling the rate of secondary succession after farmland abandonment in a Mediterranean mountain area. Landscape and Urban Planning 83: 245-254. Doi: 10.1016/j.landurbplan.2007.04.008

Qin LJ, Qin XZ, Jiang ZY. 2012. Health impact on nonagricultual working time of migrant workers. Chinese Rural Economy 12: 38-45. Doi: 10.13246/j.cnki.jae.2014.12.011

Queiroz C, Beilin R, Folke C, Lindborg R. 2014. Farmland abandonment: threat or opportunity for biodiversity conservation? A global review. Frontiers in Ecology and the Environment 12: 288-296. Doi: 10.1890/120348

Ramankutty N, Foley JA. 1999. Estimating historical changes in land cover: North American croplands from 1850 to 1992. Global Ecology and Biogeography 8: 381-396. Doi: 10.1046/j.1365-2699.1999.00141.x

RPOSS office. 2009. Data assembly of national rural permanent observation sites survey (2000-2009). China Agriculture Press (in Chinese), Beijing.

Rudel TK, Bates D, Machinguiashi R. 2002. A tropical forest transition agricultural change, out-migration, and secondary forests in the ecuadorian Amazon. Annals of the Association of American Geographers 92: 87-102.

Rudel, T.K., Coomes, O.T., Emilio Moranc, F., Angelsen, A., Xu, J., EricLambin, 2005. Forest transitions: towards a global understanding of land use change. Global Environmental Change 15, 23-31. Doi: 10.1111/1467-8306.00281

Schierhorn F, Müller D, Beringer T, Prishchepov AV, Kuemmerle T, Balmann A. 2013. Post-Soviet cropland abandonment and carbon sequestration in European Russia, Ukraine, and Belarus. Global Biogeochemical Cycles 27: 1175-1185. Doi: 10.1002/2013GB004654

Shang ZH, Cao JJ, Guo RY, Long RJ, Deng B. 2014. The response of soil organic carbon and nitrogen 10 years after returning cultivated alpine steppe to grassland by abandonment or reseeding. Catena 119: 28-35. Doi: 10.1016/j.catena.2014.03.006

Shao J, Zhang S, Li X, 2015. Farmland marginalization in the mountainous areas: characteristics, influencing factors and policy implications. Journal of Geographical Sciences 25: 701-722. Doi: 10.1007/s11442-015-1197-4

Shao J, Zhang S, Li X. 2016. Effectiveness of farmland transter in alleviating farmliand abandonment in mountain regions. Journal of Geographical Sciences 26: 203-218. Doi: 10.1007/s11442-016-1263-6

Shoyama K, Braimoh AK. 2011. Analyzing about sixty years of land-cover change and associated landscape fragmentation in Shiretoko Peninsula, Northern Japan. Landscape and Urban Planning 101: 22-29. Doi: 10.1016/j.landurbplan.2010.12.016

Sklenicka P. 2006. Applying evaluation criteria for the land consolidation effect to three contrasting study areas in the Czech Republic. Land Use Policy 23: 502-510. Doi: 10.1016/j.landusepol.2005.03.001

Song FQ, Kang MY, Zheng ZL, Wang LC, Wang GQ, Feng DX. 2012. Variations of NPP and carbon stock benefits before and after the Grain for Green Project in Northern Shaanxi. Applied Mechanics and Materials 195-196: 1237-1242. Doi: 10.4028/www.scientific.net/AMM.195-196.1237

Song X, Peng C, Zhou G, Jiang H, Wang W. 2014. Chinese Grain for Green Program led to highly increased soil organic carbon levels: a meta-analysis. Scientific Reports 4: 1-11. Doi: 10.1038/srep04460 
Terres JM, Scacchiafichia LN, Wania A, Ambarb M, Anguianoc E, Buckwelld A, Coppolae A, Gochtf A, Källströmg AN, Pointereauh P, Strijkeri D, Visekc L, Vrankenj L, Zobenak A. 2015. Farmland abandonment in Europe: identification of drivers and indicators, and development of a composite indicator of risk. Land Use Policy 49: 20-34. Doi: 10.1016/j.landusepol.2015.06.009

Tian Y, Li X, Xin L, Ma G, Li Z. 2009. Impacts of the rise of labour opportunity cost on agricultural land use changes - a case study of Ningxia Hui Autonomoous Region. Journal of Natural Resources 24: 369-377. Doi: 1000- 3037( 2009) 03- 0369- 09

Tian YJ, Li XB, Ma GX, Hao HG. 2010. Influences of labour emigration from agriculture on the production abandonment of cultivated land in ecological sensitive areas. China Land Science 24: 4-9. Doi: 10.3969/j.issn.1001-8158.2010.07.001

Toth FL, Cao GY, Hisnyik E. 2003. Regional population projections for China. Internaionla Institute for Applied Systems Analysis, interim report.

Verburg PH, van Berkel DB, van Doorn AM, van Eupen M, Heiligenberg, van den Heiligenberg HARM. 2010. Trajectories of land use change in Europe: a model-based exploration of rural futures. Landscape Ecology 25: 217-232. Doi: 10.1007/s10980-009-9347-7

Wang QF, Xiao L, Wang HB, Cao MX. 2008. Difference between statistical data, actual data and prediction data of crop area by using remote sensor imagery in Honghu City, Hubei Province. Acta Geographica Sinica 63: 587-592. Doi: $10.11821 / x b 200806003$

Wang SP, Wilkes A, Zhang ZC, Chang XF, Lang R, Wang YF, Niu HS. 2011. Management and land use change effects on soil carbon in northern China's grasslands: a synthesis. Agriculture, Ecosystems and Environment 142: 329-340. Doi: 10.1016/j.agee.2011.06.002

Weissteiner CJ, Boschetti M, Böttcher K, Carrara P, Bordogna G, Brivio PA. 2011. Spatial explicit assessment of rural land abandonment in the Mediterranean area. Global and Planetary Change 79: 20-36. Doi: 10.1016/j.gloplacha.2011.07.009

Woodhouse SP, Good JEG, Lovett AA, Fullerc RJ, Dolmana PM. 2005. Effects of land-use and agricultural management on birds of marginal farmland: a case study in the Llŷn peninsula, Wales. Agriculture, Ecosystems \& Environment 107: 331-340. Doi: 10.1016/j.agee.2004.12.006

Xiao X, Liu J, Zhuang D, Frolking S, Boles S, Xu B, Liu M, Salas W, Moore B, Li C. 2003. Uncertainties in estimates of cropland area in China: a comparison between an AVHRR-derived dataset and a Landsat TM-derived dataset. Global and Planetary Change 37: 297-306. Doi: 10.1016/S0921-8181(02)00202-3

Xie H, Wang P, Yao G. 2014. Exploring the dynamic mechanisms of farmland abandonment based on a spatially explicit economic model for environmental sustainability: a case study in Jiangxi Province, China. Sustainability 6: 1260-1282. Doi: $10.3390 / \mathrm{su} 6031260$

Xin LJ, Fan YZ, Tan MH, Jiang LG. 2009. Review of arable land-use problems in present-day China. Ambio 38: 112-115.

Yan J, Yang Z, Li Z, Li X, Xin L, Sun L. 2016. Drivers of cropland abandonment in mountainous areas: a household decision model on farming scale in Southwest China. Land Use Policy 57: 459-469. Doi: 10.1016/j.landusepol.2016.06.014

Yang $\mathrm{H}, \mathrm{Li} \mathrm{X}$. 2000. Cultivated land and food supply in China. Land Use Policy 17: 73-88. Doi: 10.1016/S0264-8377(00)00008-9

Ye Y, Fang XQ, Dai YJ, Zeng ZZ, Zhang XZ. 2006. The assimilation of farmland data and reconstructe the rate of reclamation in three provinces in Northeast China during republican period. Progress in Natural Science 16: $1419-1427$

Zeller V, Bardgett RD, Tappeiner U. 2001. Site and management effects on soil microbial properties of subalpine meadows: a study of land abandonment along a north-south gradient un the European Alps. Soil Biology \& Biochemistery 33: 639-649. Doi: 10.1016/S0038-0717(00)00208-X

Zhang K, Dang H, Tan S, Cheng X, Zhang Q. 2010. Change in soil organic carbon following the 'Grain-For-Green' Programme in China. Land degradation \& development 21: 13-23. Doi: 10.1002/ldr.954

Zhang PC, Shao GF, Zhao G, Le Master D, Parker G, Dunning, J, Li QL. 2000. China's forest policy for the 21st century. Science 2888: 2135-2136.

Zhang X, Yang J, Wang S, 2011. China has reached the Lewis turning point. China Economic Review 22: 542-554. Doi: 10.1016/j.chieco.2011.07.002

Zhang Y, Li X, Song W, 2014a. Determinants of cropland abandonment at the parcel, household and village levels in mountain areas of China: a multi-level analysis. Land Use Policy 41: 186-192. Doi: 10.1016/j.landusepol.2014.05.011

Zhang Y, Li XB, Song W, Shi TC. 2014b. Effect of agricultural labourer on cropland abandonment under land circulation at different levels in Wulong County, Chongqing City. Progress in Geography 33: 552-560. Doi: $10.11820 / \mathrm{dlkxjz.2014.04.012}$

Zhou ZC, Gan ZT, Shangguan ZP, Dong ZB. 2009. China's Grain for Green Program has reduced soil erosion in the upper reaches of the Yangtze River and the middle reaches of the Yellow River. International Journal of Sustainable Development \& World Ecology 16: 234-239. Doi: 10.1080/13504500903007931

Zou Y. 1997. Realizing a dynamic balance of total cultivated land to support a continuous, fast and healthy development of the national economy, China Land Yearbook. China Land Press, Beijing, China.

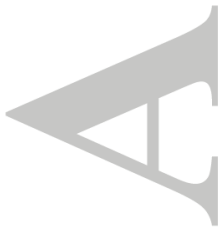


Table 1 Summary of variable statistics

\begin{tabular}{|c|c|c|c|c|c|}
\hline Variable & Description & Mean & Std. Dev. & Min & Max \\
\hline \multicolumn{6}{|c|}{ Dependent variables } \\
\hline CAPAL & $\begin{array}{l}\text { Cropland area per standard agricultural } \\
\text { labourer in the village }(\mathrm{mu})\end{array}$ & 3.68 & 3.34 & 0.36 & 21.58 \\
\hline \multicolumn{6}{|c|}{ Independent variables } \\
\hline & $\begin{array}{l}\text { Agricultural productive fixed assets } \\
\text { (including agricultural machinery and } \\
\text { transportation) per household per } \\
\text { agricultural labourer in the village (Yuan, } \\
\text { comparable prices in 2000) }\end{array}$ & 972.64 & 1399.55 & 0.00 & 13870.00 \\
\hline$D A F$ & $\begin{array}{l}\text { Number draught animals per agricultural } \\
\text { labourer in the village }\end{array}$ & 0.15 & 0.18 & 0.00 & 1.62 \\
\hline$A P S$ & $\begin{array}{l}\text { Average area per cropland parcel in the } \\
\text { village }(\mathrm{mu})\end{array}$ & 1.30 & 1.42 & 0.08 & 8.74 \\
\hline FCINDEX & $\begin{array}{l}\text { The percentage of forest area divided by the } \\
\text { proportion cropland area }\end{array}$ & 9.57 & 18.10 & 0.00 & 99.00 \\
\hline Land $r$ & $\begin{array}{l}\text { Ratio of leasing land to all cropland in } \\
\text { the village }(\%)\end{array}$ & 4.88 & 8.98 & 0.00 & 75.81 \\
\hline & $\begin{array}{l}\text { The sum of areas under various crops raised } \\
\text { in a single years divided by net area of } \\
\text { cropland in the village }\end{array}$ & 1.71 & 1.02 & 0.25 & 9.40 \\
\hline$P P F$ & $\begin{array}{l}\text { The proportion of paddy fields in croplands } \\
(\%)\end{array}$ & 0.30 & 0.35 & 0.00 & 1.00 \\
\hline Dl & $\begin{array}{l}1 \text { if the village in Inner Mongolia and the } \\
\text { Great Wall region, } 0 \text { if otherwise }\end{array}$ & 0.03 & 0.16 & 0.00 & 1.00 \\
\hline D2 & $\begin{array}{l}1 \text { if the village in Huang-Huai-Hai region, } 0 \\
\text { if otherwise }\end{array}$ & 0.05 & 0.22 & 0.00 & 1.00 \\
\hline & $\begin{array}{l}1 \text { if the village in Loess plateau region, } 0 \text { if } \\
\text { otherwise }\end{array}$ & 0.26 & 0.44 & 0.00 & 1.00 \\
\hline D4 & $\begin{array}{l}1 \text { if the village in Gansu-Xinjiang region, } 0 \\
\text { if otherwise }\end{array}$ & 0.01 & 0.10 & 0.00 & 1.00 \\
\hline D5 & $\begin{array}{l}1 \text { if the village in the middle and lower } \\
\text { reaches of Yangtze River, } 0 \text { if otherwise }\end{array}$ & 0.15 & 0.36 & 0.00 & 1.00 \\
\hline D6 & $\begin{array}{l}1 \text { if the village in South region, } 0 \text { if } \\
\text { otherwise }\end{array}$ & 0.11 & 0.31 & 0.00 & 1.00 \\
\hline D7 & $\begin{array}{l}1 \text { if the village in Southwest region, } 0 \text { if } \\
\text { otherwise }\end{array}$ & 0.27 & 0.45 & 0.00 & 1.00 \\
\hline$D 8$ & $\begin{array}{l}1 \text { if the village in Tibet Plateau, } 0 \text { if } \\
\text { otherwise }\end{array}$ & 0.01 & 0.10 & 0.00 & 1.00 \\
\hline
\end{tabular}


Table 2 Conversion coefficient of labour force to standardized agricultural labour

\begin{tabular}{ccccc}
\hline Groups & Gender-CC & Age-CC & Farming-time-CC & Overall-CC \\
\hline Male \& under 60 \& full-time & 1 & 1 & 1 & 1 \\
Male \& under 60 \& part-time & 1 & 1 & 0.5 & 0.5 \\
Male \& over 60 \& full-time & 1 & 0.5 & 1 & 0.5 \\
Male \& over 60 \& part -time & 1 & 0.5 & 1 & 0.5 \\
Female \& under 60 \& full-time & 0.8 & 1 & 0.5 & 0.8 \\
Female \& under 60 \& part-time & 0.8 & 1 & 1 & 0.4 \\
Female \& over 60 \& full-time & 0.8 & 0.5 & 0.5 & 0.2 \\
\hline Female \& over 60 \& part -time & 0.8 & 0.5 & & \\
\hline
\end{tabular}

Table 3 Custom-to-standard coefficients for each province

\begin{tabular}{|c|c|c|}
\hline CTS efficient & Applicable provinces & References \\
\hline 1.0 & Xinjiang, Tibet & - \\
\hline 1.1 & Liaoning, Yunnan & $\begin{array}{c}\text { (Hong, 2007; Ye et al., 2006) \& Rural } \\
\text { household survey }\end{array}$ \\
\hline 1.2 & Guangxi, Hunan, Hainan & Rural household survey \\
\hline 1.3 & Jiangxi & $\begin{array}{c}\text { (Liao, 2005) \& Rural household } \\
\text { survey }\end{array}$ \\
\hline 1.4 & Zhejiang & Rural household survey \\
\hline 1.5 & Ningxia & $\begin{array}{c}\text { (Hong, 2007) \& Rural household } \\
\text { survey }\end{array}$ \\
\hline 1.5 & Guangdong & $\begin{array}{c}\text { (Kuang et al., 2002) \& Rural } \\
\text { household survey }\end{array}$ \\
\hline 1.5 & Hubei & $\begin{array}{l}\text { (Wang et al., 2008) \& Rural } \\
\text { household survey }\end{array}$ \\
\hline 1.5 & $\begin{array}{l}\text { Beijing, Hebei, Shanxi, Anhui, Fujian, Shandong, } \\
\text { Henan, Sichuan, Shaanxi, Gansu, Qinghai, } \\
\text { Guizhou, Heilongjiang, Jilin, Inner Mongolia }\end{array}$ & Rural household survey \\
\hline 2.0 & Chongqing & Rural household survey \\
\hline
\end{tabular}


Table 4 Scenarios for the Rural National Population Projection

\begin{tabular}{|c|c|c|c|c|c|}
\hline \multirow{2}{*}{ Periods } & \multicolumn{2}{|c|}{ Life Expectancy (age) } & \multirow{2}{*}{ TFR } & \multicolumn{2}{|c|}{ Net Migration (million persons) } \\
\hline & Males & Females & & Males & Females \\
\hline 2010-2015 & 73.1 & 78.3 & 1.43 & 56.87 & 56.04 \\
\hline 2015-2020 & 73.6 & 78.6 & 1.53 & 45.39 & 44.88 \\
\hline $2020-2025$ & 74.1 & 78.9 & 1.65 & 33.34 & 32.95 \\
\hline $2025-2030$ & 74.6 & 79.2 & 1.79 & 26.85 & 26.51 \\
\hline
\end{tabular}

Table 5 Multiple regression results

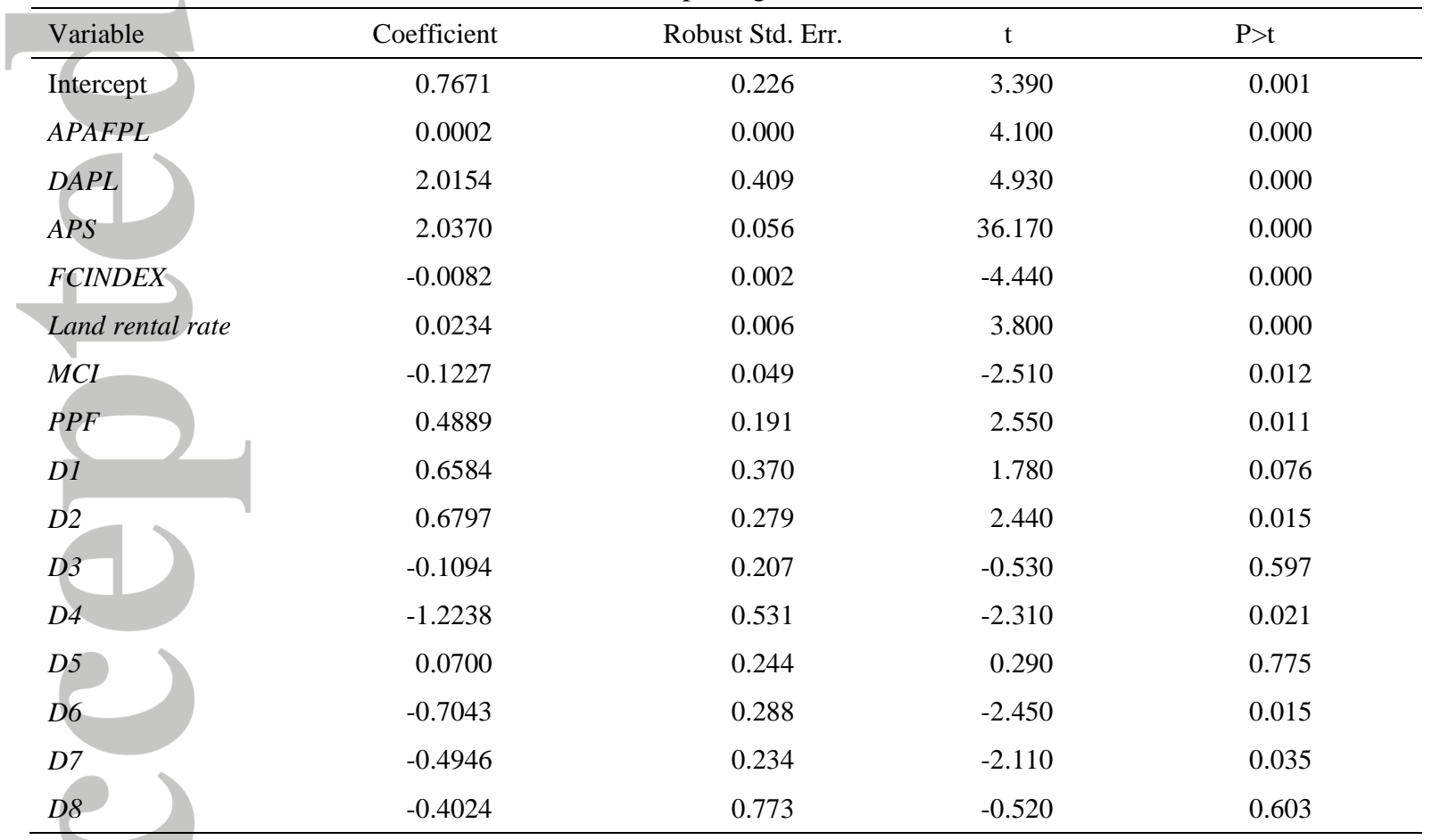




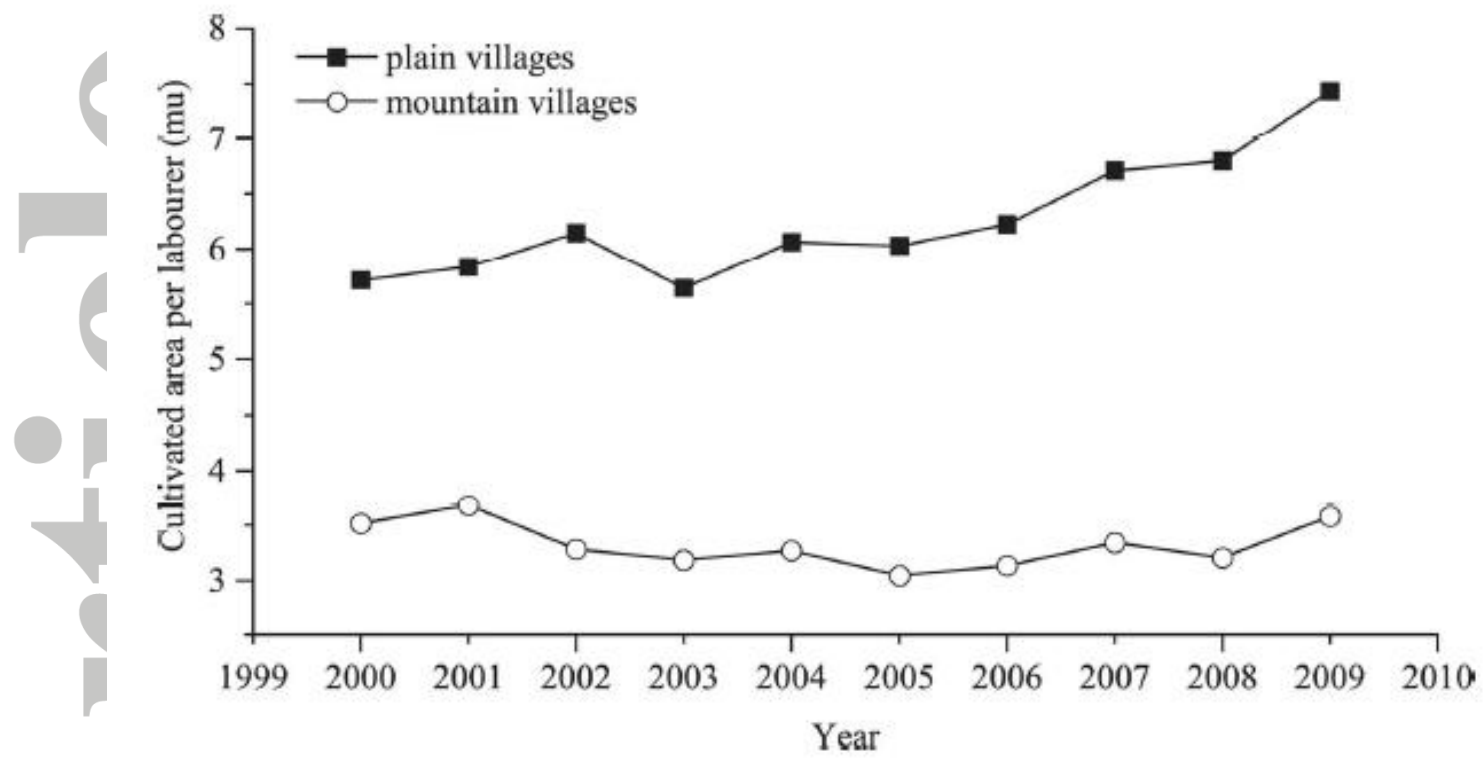

Figure 1.The enlarging gap of cultivated area per labors between mountain and plain areas

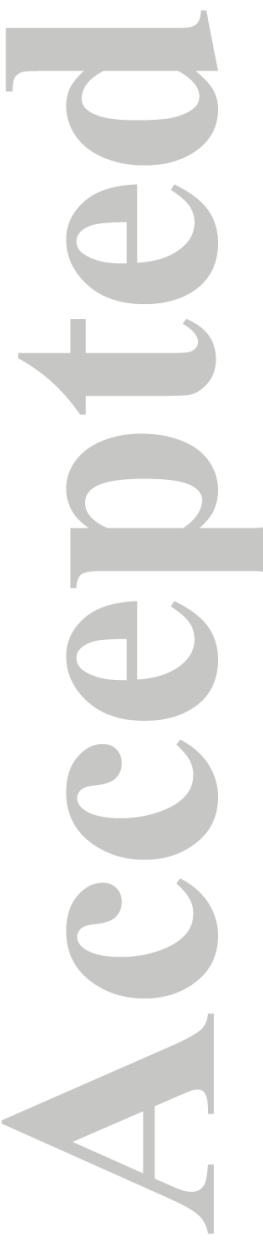

This article is protected by copyright. All rights reserved. 


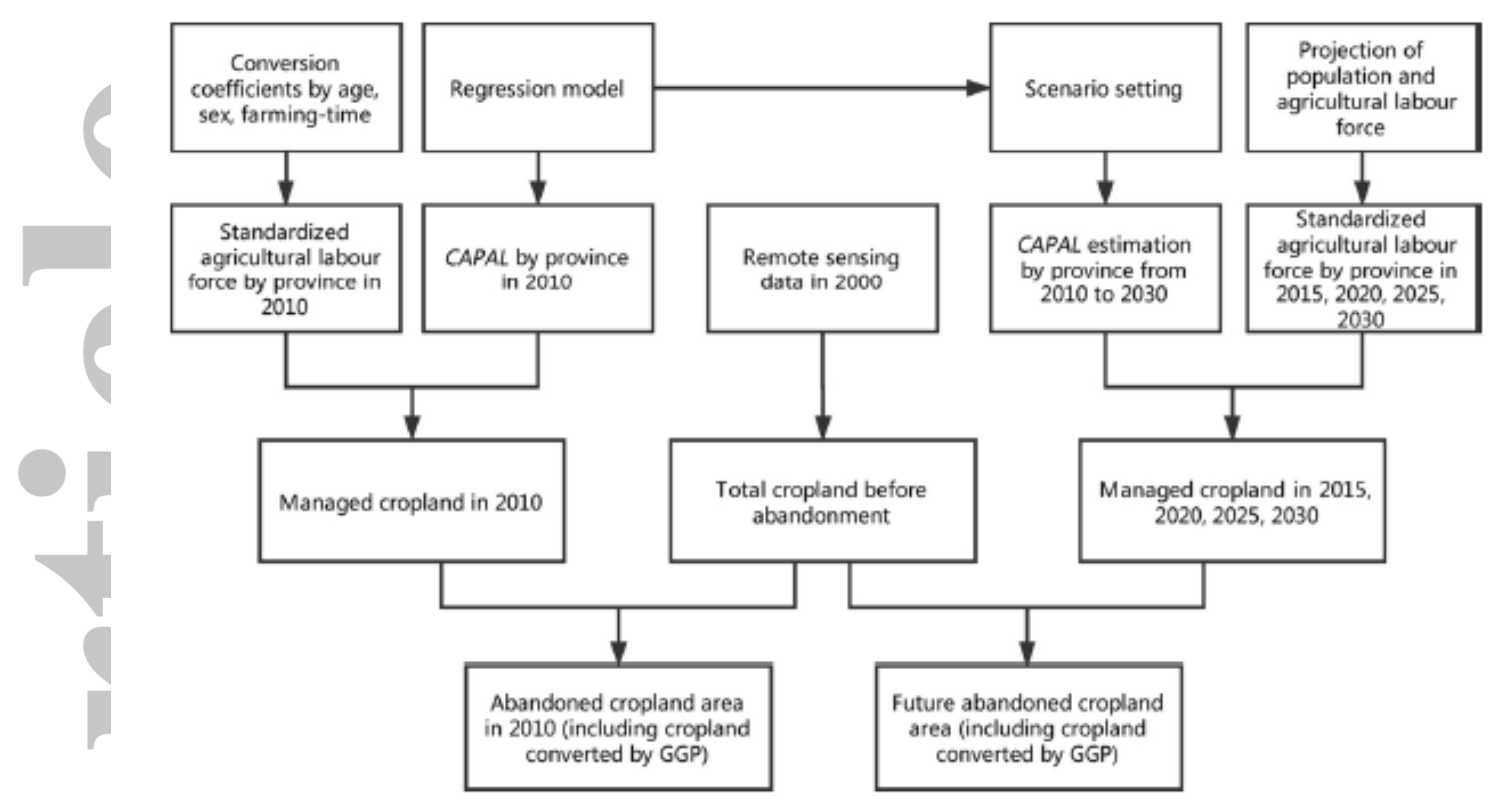

Figure 2. Generally framework for the estimation of the extent of abandoned cropland 

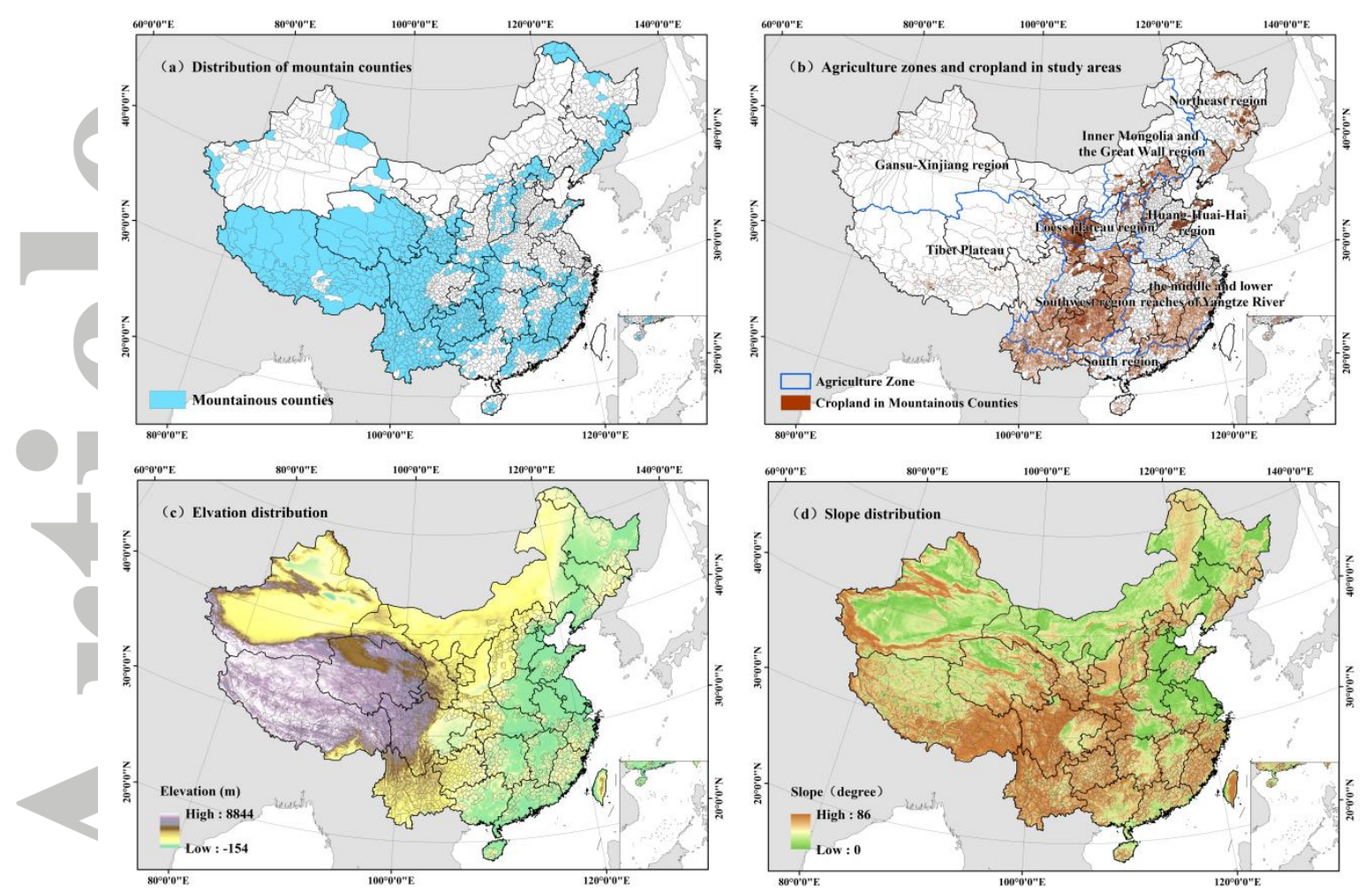

Figure 3 The distribution of mountainous counties and the cropland inside them and the terrain characteristic in China.

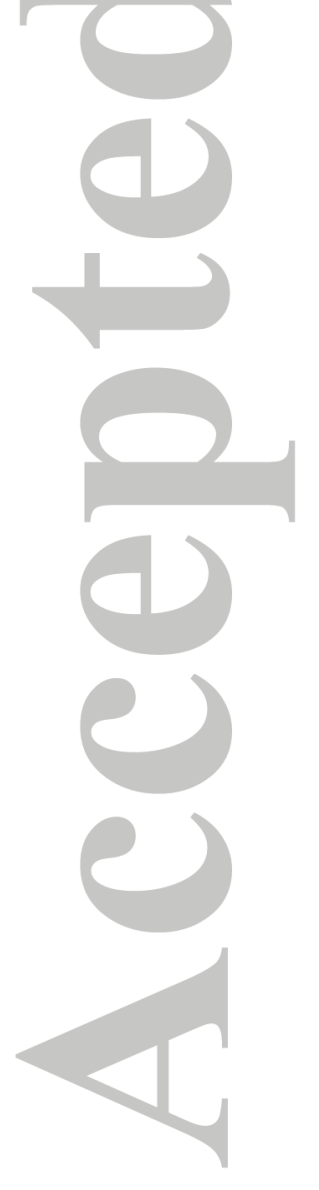

This article is protected by copyright. All rights reserved. 

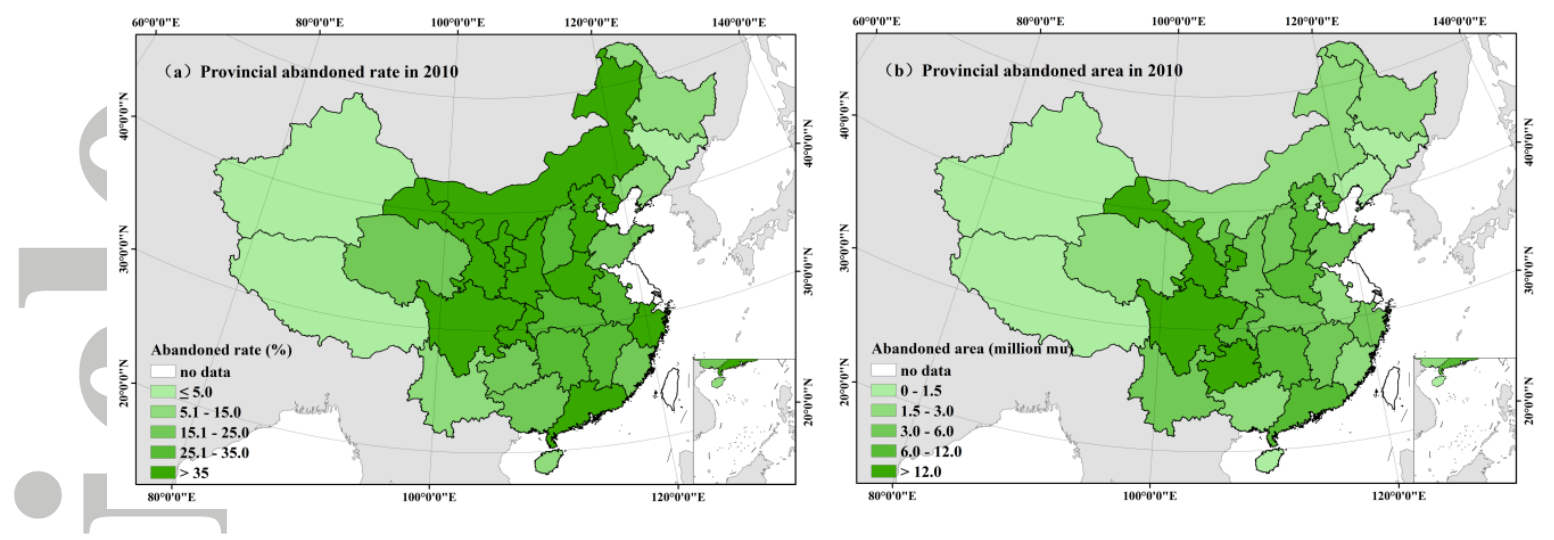

Figure 4 Maps of abandoned rate and abandoned area of mountainous counties in 2010
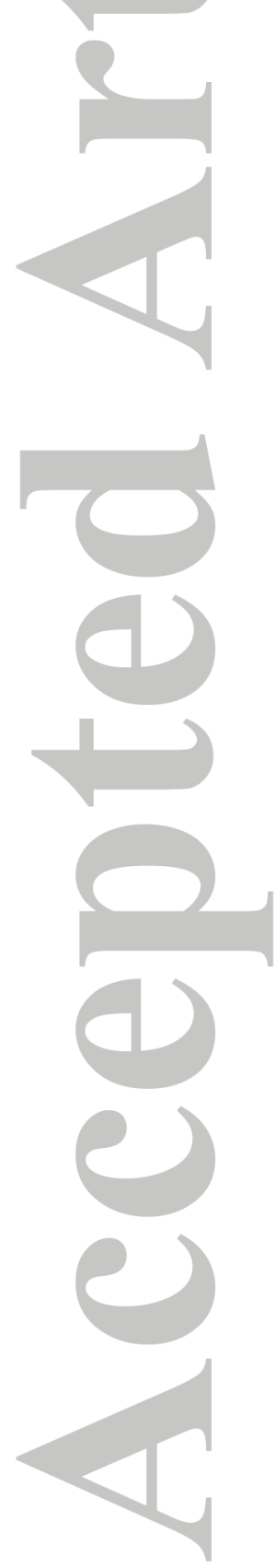

This article is protected by copyright. All rights reserved. 


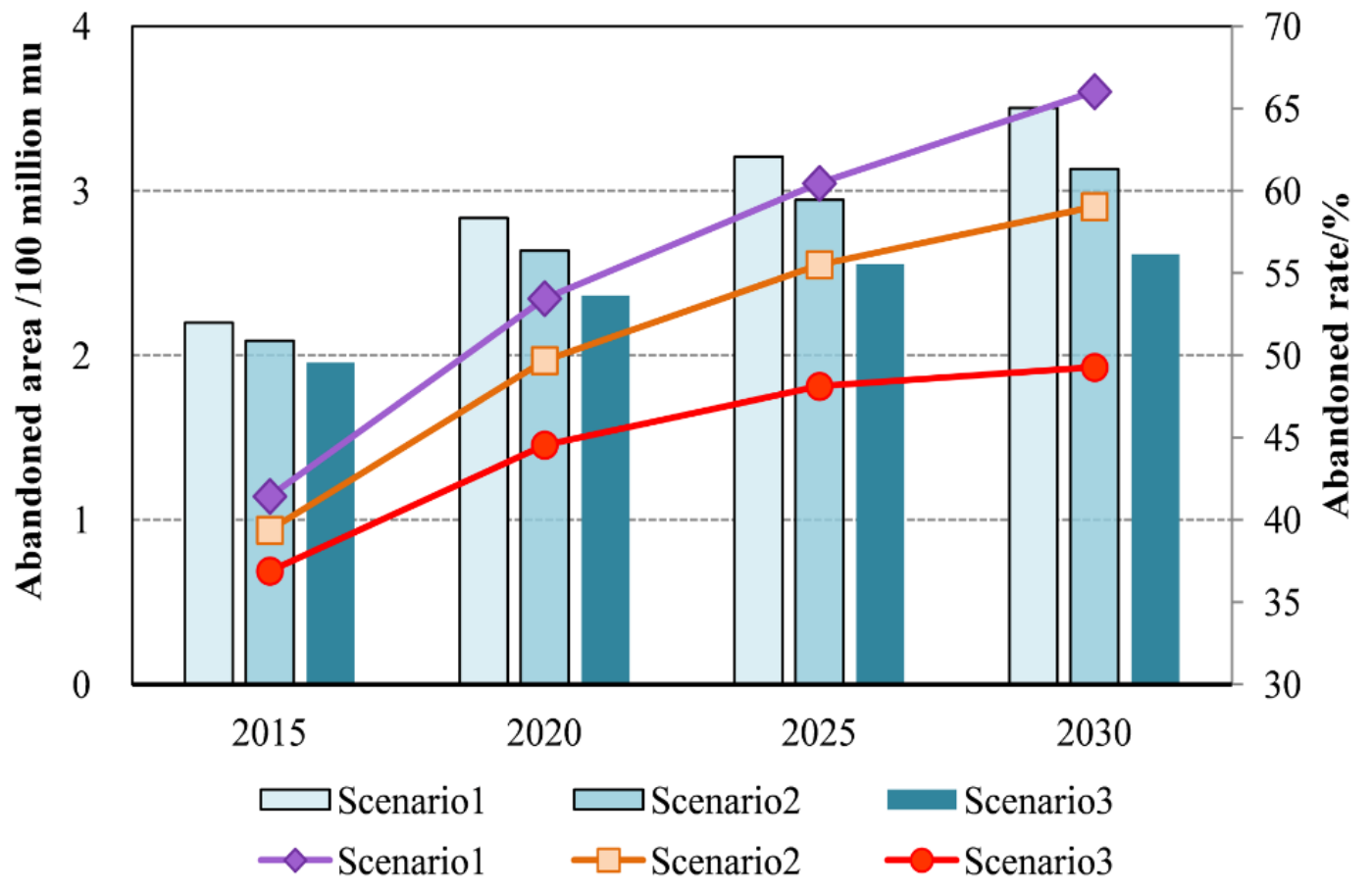

Figure 5 Predictions of total Abandoned Area in Mountainous Counties since 2000

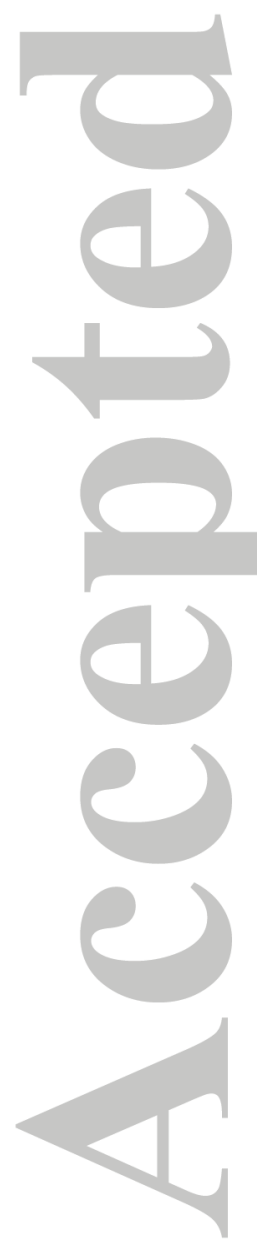

This article is protected by copyright. All rights reserved. 